\title{
Phagotrophic protists (protozoa) in Antarctic terrestrial ecosystems: diversity, distribution, ecology, and best research practices
}

\author{
Andrew R. Thompson ${ }^{1}$ (i)
}

Received: 27 August 2019 / Revised: 13 March 2021 / Accepted: 4 June 2021 / Published online: 18 June 2021

(c) The Author(s) 2021

\begin{abstract}
Phagotrophic protists (formerly protozoa) are a highly diverse, polyphyletic grouping of generally unicellular, heterotrophic eukaryotes that are key regulators of the soil microbiome. The biodiversity and ecology of soil phagotrophic protists are still largely uncharacterized, especially in the Antarctic, which possesses some of the harshest terrestrial environments known and potentially many physiologically unique and scientifically interesting species. Antarctic soil systems are also highly limited in terms of moisture, temperature, and carbon, and the resulting reduced biological complexity can facilitate finetuned investigation of the drivers and functioning of microbial communities. To facilitate and encourage future research into protist biodiversity and ecology, especially in context of the broader functioning of Antarctic terrestrial communities, I review the biodiversity, distribution, and ecology of Antarctic soil phagotrophic protists. Biodiversity appears to be highly structured by region and taxonomic group, with the Antarctic Peninsula having the highest taxonomic diversity and ciliates (Ciliophora) being the most diverse taxonomic group. However, richness estimates are likely skewed by disproportionate sampling (over half of the studies are from the peninsula), habitat type bias (predominately moss-associated soils), investigator bias (toward ciliates and the testate amoeba morphogroup), and methodological approach (toward cultivation and morphological identification). To remedy these biases, a standardized methodology using both morphological and molecular identification and increased emphasis on microflagellate and naked amoeba morphogroups is needed. Additionally, future research should transition away from biodiversity survey studies to dedicated ecological studies that emphasize the function, ecophysiology, endemicity, dispersal, and impact of abiotic drivers beyond moisture and temperature.
\end{abstract}

Keywords Antarctic protozoa Abiotic drivers of protist communities $\cdot$ Phagotrophic soil protists $\cdot$ Protist diversity $\cdot$ Corythion dubium

\section{Introduction}

Identifying links between biodiversity and function in soils is a priority for understanding both fundamental ecological principles as well as for predicting and mitigating the effects of climate change on the biosphere (Wall 2005, 2007; Nielsen et al. 2011; Chakraborty et al. 2012; Potter et al. 2013). Phagotrophic soil protists play critical roles in regulating soil bacterial communities and influencing plant functioning (Geisen et al. 2017; Gao et al. 2019; Singer et al. 2021). Due to their intermediary size, phagotrophic protists form an essential link between soil bacteria and metazoan

Andrew R. Thompson

andrew.thompson8956@gmail.com

1 Department of Biology, Brigham Young University, 4102 LSB, Provo, UT 84606, USA predators, like nematodes, which are too large to exploit many micro-soil habitats where bacteria are capable of thriving (Wilkinson et al. 2012). Phagotrophic protists can increase the productivity of microbial communities by maintaining log-scale growth among prey species and encouraging the growth of less abundant species (Crotty et al. 2012; Saleem et al. 2012, 2013). Phagotrophic protists also prey on other groups, including fungi, other protists, nematodes and other micro-metazoa (Bjørnlund and Rønn 2008; Rønn et al. 2012; Geisen et al. 2015; Geisen 2016; Park et al. 2017a). Fewer studies have focused on these interactions, but they are likely to be more commonplace and important for food web structure than previously thought (Geisen 2016). Recent work thus shows how crucial soil protist research is to understanding general rules about soil community stability, resilience, and nutrient cycling. 
However, the extent and nature of the influence of phagotrophic protists on soil community dynamics and nutrient cycling is not well understood (Wardle 2006; Corno and Jurgens 2008; Saleem et al. 2013; Geisen 2016; Geisen et al. 2017). One reason may be that soils are highly diverse ecosystems and characterizing the sheer number and variety of biotic and abiotic interactions that are present is unfeasible (Bardgett and van der Putten 2014). Because of its harsh climate, continental Antarctica is home to some of the most depauperate soils on earth (Wall 2005; Convey et al. 2008), potentially facilitating the investigation of fundamental questions about the functional roles phagotrophic protists play in soil ecosystems (Fell et al. 2006; Thompson et al. 2020). Extreme low average temperatures, limited growth periods, very little liquid water, and highly nutrient limited and saline soils severely restrict biotic diversity (Adams et al. 2006; Barret et al. 2006; Priscu 2013). Although moss-associated soil habitats exist on the continent in areas that are consistently moist (Foissner 1987, 1996; Broady 1989; Block 1994; Barman 2000; Bamforth et al. 2005), generally the largest concentration of mosses is found at higher latitudes in the NAP, where they form expansive banks (Royles et al. 2016). Instead, most ice-free regions consist of poorly developed and frequently unvegetated mineral soils that possess some of the lowest levels of bioavailable carbon in any terrestrial ecosystem (Burkins et al. 2001; Convey et al. 2008). They are also characterized by high levels of salt (due to a general lack of leaching processes), little to no precipitation (and almost always in the form of snow when it does occur), and low moisture (Block 1994; Priscu 2013). During the winter, temperatures at terrestrial sites are almost constantly below the known lower threshold for biological activity $\left(\sim-20^{\circ} \mathrm{C}\right.$; see Kolb (2014)) and even during the summer, soils can frequently drop below temperatures at which most organisms are able to remain active (Knox et al. 2015; Goordial et al. 2016).

The influence that phagotrophic protists have on soil processes is primarily through species-specific interactions, modulated by distribution, ecophysiology, prey preference, and life history traits of the protists themselves and their prey, predators, and pathogens (Bell et al. 2010; Glucksman et al. 2010; Rønn et al. 2012; Saleem et al. 2013). Understanding the nature of these interactions in any system requires intimate knowledge of the taxonomic and functional diversity of phagotrophic protists (Glucksman et al. 2010), yet there is currently a dearth of information in this regard (Rønn et al. 2012; Wilkinson et al. 2012; Geisen 2016). In protists, certain ecological functions (e.g., feeding preferences) can be inferred from taxonomy (Adl et al. 2019). However, relatively little work has been done to assess taxonomic diversity in Antarctic terrestrial environments over the last century (Acuña-Rodríguez et al. 2014) and the most recent reviews are now two decades old (Smith
1996; Foissner 1998). Thompson et al. (2019) constructed a species checklist of phagotrophic protists in Antarctica by reviewing all relevant literature (Online Resource 1), arriving at a total of 236 species and 303 additional taxa not identified to species (Online Resource 2). Using this checklist and its literature reviewed as a baseline, I examine how phagotrophic protist diversity is structured at the regional scale (Terauds et al. 2012; Terauds and Lee 2016). I also explore how phagotrophic protist diversity differs by habitat type, specifically mineral soils and mosses, and how these organisms are influenced by abiotic and biotic drivers. Finally, I discuss the biases in our current understanding of this diversity, the challenges associated with assessing it, and what can be done to overcome each.

\section{Approach to literature review and data analysis}

The literature reviewed in this study was found by searching variants of relevant keywords (see Thompson et al. (2019) for the full list) in Web of Science, SCOPUS, and Google Scholar, and by following citation chains. A list of all studies and a database containing all taxonomic entries pulled from the reviewed literature, including notes on various metadata including sample source, location, and isolation techniques, are included in two supplemental tables (Online Resource 1 and 2). A third supplemental table (Online Resource 3) lists all taxonomic entries, including those not identified to species, organized by modern taxonomic groups (e.g., Amoebozoa, Cercozoa, and Discoba; see Adl et al. (2019)), and presents their occurrence by biogeographic region (Terauds et al. 2012; Terauds and Lee 2016) and habitat type (e.g., soil or moss). Because many of the original identifications were based on morphology alone, and it is now known that accurate identification requires molecular characters for many species (Haentzsch et al. 2006; Howe et al. 2009; Kosakyan et al. 2013; Venter et al. 2018), I only used taxa identified to species for my analyses, and only analyzed patterns at higher taxonomic levels. Even still, the results discussed herein should be considered as preliminary and a foundation with which to frame future research into protist biodiversity and ecology in Antarctica.

Protist taxonomy has undergone major revisions in recent decades at both high and low taxonomic levels (Adl et al. 2005, 2007, 2012, 2019; Ruggiero et al. 2015), and thus the taxonomy for the identified species in the review has been updated (Thompson et al. 2019). Protists were traditionally organized, using motility as a distinguishing characteristic, into ciliates, testate amoebae, naked amoebae, and flagellates; only ciliates are still considered monophyletic (i.e., Ciliophora; see Adl et al. (2019)). Modernly, testate amoebae are found among the Cercozoa, Amoebozoa, and 
Stramenopiles; naked amoebae are common among the Amoebozoa, but are found across the eukaryotic tree of life, including in the Cercozoa, Endomyxa, Heterolobosea, Filasterea, Nucleariida, and Stramenopiles; and flagellated protists are heavily polyphyletic and are included in virtually every major protistan clade (Adl et al. 2005, 2007, 2012, 2019). Because the studies reviewed herein span this transitional period in protistan nomenclature, many studies often used drastically different naming schemes. To bridge this gap, I discuss patterns in diversity using both old (motility-based) and recent (molecular-based) nomenclature. Although taxonomically obsolete, the motility-based nomenclature is still useful for two reasons: (1) this review is intended for non-protist experts who will encounter these organisms in the field and will initially recognize the organisms by their motility; (2) the traditional motility-based nomenclature is still ecologically relevant since a protist's function is influenced by its motility type (Rønn et al. 2012).

Experimental designs across studies varied, differing in terms of approach (methodology and target biota), scope (sampling effort), and metadata detail. For example, out of 53 studies, eight were not surveys (for examples, see Park et al. (2017a), Park et al. (2018)), and 14 did not report sample number, making comparisons between studies and regions challenging. In order to include all relevant studies, I used the number of studies per region (which correlated strongly with richness estimates, $R^{2}=0.95$; see Online Resource 4, Fig. S1) instead of sample numbers to evaluate trends in richness and distribution. For discussions of the biogeography of phagotrophic protists in Antarctica, I modified Fig. 1 from Terauds and Lee (2016) to show the location of and methodology used by each study reviewed (see Fig. 1). Less than $0.5 \%$ of the Antarctic landmass is ice-free (Burton-Johnson et al. 2016), with ice-free regions primarily located on the Antarctic Peninsula, along the Transantarctic Mountains, and around the rim of the continent. Terauds et al. (2012) and Terauds and Lee (2016) organized these ice-free habitats into 16 distinct bioregions using the regional structure of abiotic variables, available taxon biogeography, expert opinion, and considerations of dispersallimiting landscape features. Due to a paucity of records from certain bioregions, I consolidated Northwest and Northeast Antarctic Peninsula into North Antarctic Peninsula, and Central South and South Antarctic Peninsula into South Antarctic Peninsula. For the discussion of diversity across habitat types, I assigned all taxa identified to species for which habitat information was recorded (Online Resource 2) to one of four categories: 'Soil', 'Moss', 'Soil and Moss',

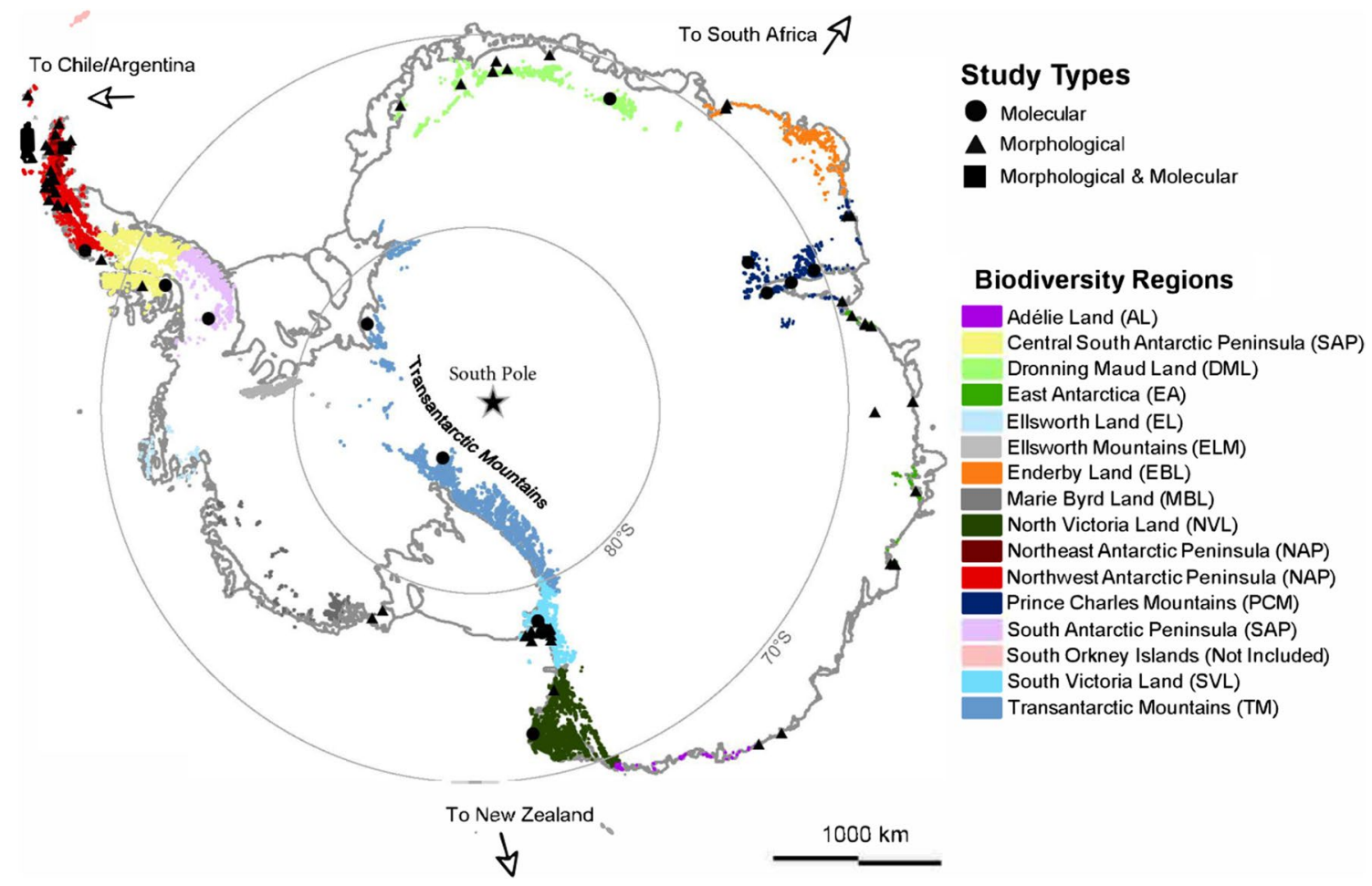

Fig. 1 Study locations and methodological type. Locations of regional study sites for all 53 studies, underlain by Fig. 1 from Terauds and Lee (2016) showing all 16 Antarctic biodiversity regions, modified using arcmap GIS and Adobe Illustrator. Ice-free regions are colored, different colors designate the different biodi- versity regions. Triangles indicate morphology-only studies, circles molecular-only studies, and squares those studies that used both morphological and molecular approaches. Arrows around the exterior show the general direction to other landmasses (i.e., Chile/Argentina, South Africa, and New Zealand) 
and 'Other' which includes samples that were ornithogenic, vegetated (beyond mosses), or had unclear terrestrial origins. Samples that could have been aquatic or benthic in origin were excluded (Decloître 1960, 1964; Hada 1964; Hodgson et al. 2010). A fifth category, "Not Reported", encompasses those five species that did not have any associated habitat information (Online Resource 3). Although the habitat type categories used in this paper are strictly dichotomous and the difference between terrestrial moss and pure soil habitats is not (e.g., whether a moss sample also included the soil beneath), detailed metadata distinguishing between habitat types were not usually made in the studies reviewed, so a conservative approach was used.

\section{Taxonomic diversity of phagotrophic protists across Antarctic biodiversity regions}

Thompson et al. (2019) discussed the diversity of the Antarctic continent and peninsula as a whole (an estimated 539 distinct taxa), and in this section I will discuss that diversity in terms of regions, taxonomy, and habitat type. The North Antarctic Peninsula (NAP), East Antarctica (EA), and South Victoria Land (SVL) had an order of magnitude higher taxonomic richness $(155,52$, and 50 species, respectively) than the rest of the regions (all of which hade 5 or fewer species with the exception of Adélie Land (AL), Enderby Land (EBL) and Dronning Maud Land (DML) which had 10, 15, and 12 species, respectively (Fig. 2A). More than half of the records $(56 \%)$ were for taxa that were not identified to species, but this trend was not even across regions. EBL had the most taxa not identified to species (86\%), while the two regions with the greatest proportion of studies (SVL and
NAP) had the fewest (38\% and 29\%; Fig. 2B). How much phagotrophic protist diversity remains to be discovered has already been discussed recently (Thompson et al. 2019), but the results of a recent shotgun metagenome study in SVL (Thompson et al. 2020) suggest that diversity is potentially much higher than previously thought in even well-studied regions.

\section{Trends in the biogeography of Antarctic phagotrophic protists}

Antarctic phagotrophic protist diversity appears to be fairly heterogeneous and distinct from region to region; no single region in Antarctica captures the entire diversity of the whole continent. Overall, $81 \%$ of all taxa identified to species are unique to one region (Fig. 3). The origin of such high heterogeneity has two possible biological explanations: the first is that species unique to each region may represent endemic species that survived the last glacial maximum (LGM) in glacial refugia, an increasingly common and well-supported explanation for the endemicity of a number of other Antarctic biotic groups (Convey et al. 2009; Fraser et al. 2014). However, whether phagotrophic protists recolonized ice-free habitat after the LGM has yet to be tested. Alternatively, regional endemicity could indicate that the connectivity between Antarctic regions and the nearest nonAntarctic source pools, e.g., the southernmost tip of South America for the Antarctic Peninsula (Fernández 2015), is greater than between Antarctic regions themselves. This seems reasonable for peninsular communities due to their proximity to South America and the chain of islands that bridge the distance between the two landmasses (Smith 1978). However, the distance between other Antarctic
A

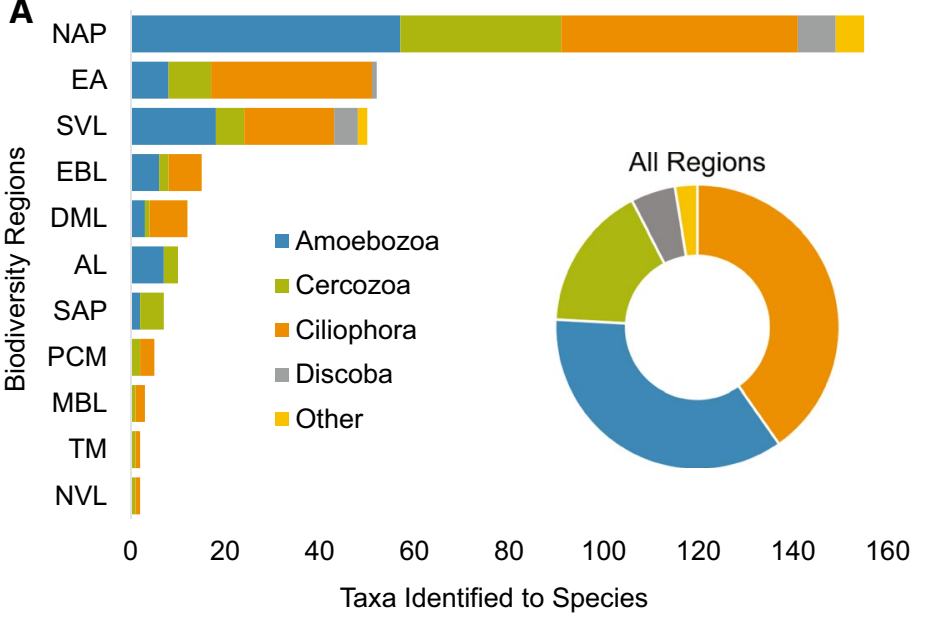

B

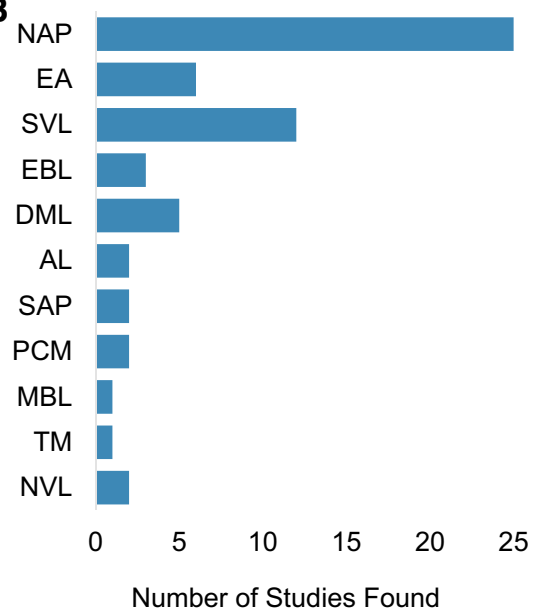

Fig. 2 Alpha diversity and studies counts by biodiversity region. A Phylum/supergroup-level species richness by biodiversity region as outlined in Terauds and Lee (2016) using only taxa identified to the species level. 'Other' includes phagotrophic members of the Stramenopiles, Apicomplexa, Dinozoa, Nucleariids and Choanoflagellates. B Number of studies found for each region 


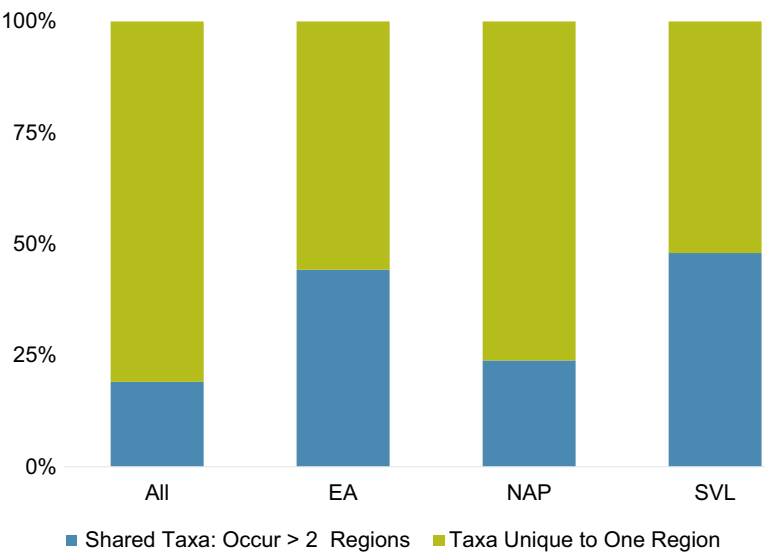

Fig. 3 Ratio of shared to unique taxa by region. Taxa identified to species from each region were compared to determine which occurred in at least two regions. Regions with $<15$ taxa were excluded

regions and corresponding extra-continental source pools, e.g., South Africa and EA, and New Zealand and Victoria Land (see Fig. 1), is far greater and contains fewer intervening islands, making this explanation potentially less likely outside of the peninsular Antarctic. Testing this hypothesis in the future will require caution: the existence of cryptic species among protists makes comparisons of fauna from different locations difficult without molecular work (Smirnov and Brown 2004; Adl et al. 2007; Venter et al. 2018). Some evidence suggests that apparently cosmopolitan protist taxa in Antarctica exhibit distinct ecophysiological traits (e.g., body size and temperature preferences; Bamforth et al. (2005), Royles et al. (2016)) and may therefore be genetically distinct lineages. Whatever the cause of the heterogeneous regional diversity, such a high degree of heterogeneity suggests that intra-continental dispersal of protists between regions is limited. Alternatively, the high heterogeneity could also be an artifact of regional sampling biases as over half of the studies were conducted in just two of the 13 biodiversity regions (NAP and SVL).

An interesting pattern in Antarctic biodiversity is the striking difference between the communities of the Peninsula and the rest of the continent (Chown and Convey 2007). This division is delineated by the Gressit line and holds true for many metazoa (i.e., nematodes, tardigrades, free-living mites, and springtails) and bryophytes (Cannone et al. 2013) but has not been tested in eukaryotic or prokaryotic microbes (Chown and Convey 2007). Comparing total peninsular diversity (NAP with SAP; 156 species) to combined continental diversity (EBL, SVL, NVL, EA, PCM, TM, AL, MBL, and DML; 118 species) revealed 39 shared species. The peninsula produced a combined total of 27 studies and the continent 36 (Fig. 2B), suggesting that this result may not purely be a result of study number bias. Another reasonable explanation for the differences between the peninsula and the continent is the difference in climate. Broadly, the climate becomes increasingly extreme (drier and colder) as one moves toward the interior of the continent (Block 1994; Lawley et al. 2004; Convey et al. 2014) and, indeed, latitudinal studies on phagotrophic protist biodiversity trends within Antarctica show decreasing diversity with increasing latitude (Smith 1982; Foissner 1996; Lawley et al. 2004).

\section{Diversity by lineage and the most widely distributed taxa}

Ciliophora account for the largest proportion of Antarctic phagotrophic protists, followed by Amoebozoa, Cercozoa, Discoba and then members of the Opisthokonta, Apicomplexa, Stramenopiles and non-ciliate Alveolates (collectively referred to hereafter as "Other"; Fig. 2A). In a latitudinal study (Lawley et al. 2004), both Cercozoa and Ciliophora were found at all latitudes sampled, while Euglenozoa (Discoba) were not found south of the NAP. Numerous other studies have found Euglenozoa in EA, EBL, SVL and the NAP (Sudzuki 1979; Smith 1985; Bamforth et al. 2005) (Online Resource 2). EA, SVL and NAP possess a similar relative composition of Ciliophora, Amoebozoa and Cercozoa, even though study number are not equal between them (Fig. 2B)-i.e., EA and SVL have around one third the recorded species as the NAP. Amoebozoa and Ciliophora dominate these three regions in terms of relative richness (Fig. 2A), and there is a strong bias toward amoebozoan testate amoebae. Well over half of Amoebozoa taxa in the NAP, EA and EBL are testates (75\%, 100\% and 100\% respectively), while SVL Amoebozoa are slightly more diverse (only $39 \%$ testate amoeba). Cercozoan testate amoebae are similarly dominant in the records, making up 71\%, $100 \%, 100 \%$, and $67 \%$ of total Cercozoa in these regions, respectively. Amoebozoa are not reported from MBL, the TM, NVL or the PCM, while Ciliophora are reported from every region except $\mathrm{AL}$ and $\mathrm{SAP}$, where the authors of the only studies in these regions exclusively targeted testate amoebae (Decloître 1960, 1964; Royles et al. 2013). These observations reflect the fact that most morphological studies focused exclusively on either testate amoebae (Penard 1911, 1913; Decloître 1960, 1964; Smith 1987; Todorov and Golemansky 1996) or ciliates (Ryan et al. 1989; Foissner 1996; Petz and Foissner 1996, 1997; Petz 1997; Mieczan and Tarkowska-Kukuryk 2014; Velasco-Castrillón et al. 2014) (Fig. 4). Possibly because of this investigator bias, testate amoeba diversity and distribution, especially in the NAP, are relatively well understood (Royles et al. 2016; Roland et al. 2017). There is no apparent investigator bias toward testate amoebae and ciliates among molecular studies, but such studies do recover fewer amoebozoan sequences (2 out of 22 sequences from all molecular studies) than other 


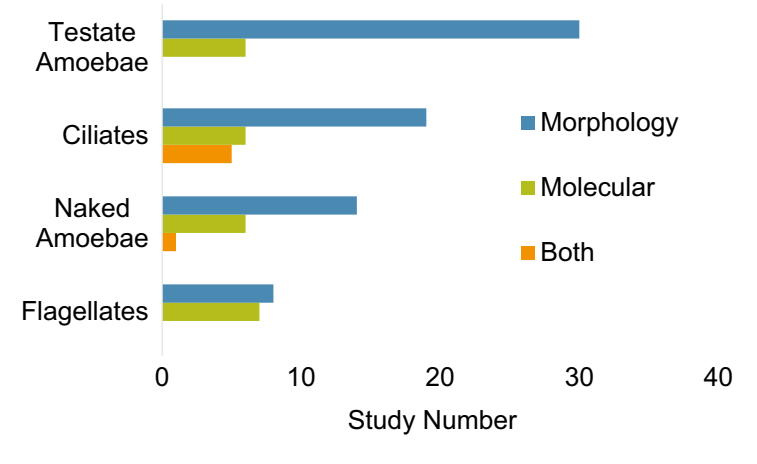

Fig. 4 Overall study target bias by morphological group. Taxonomic targets of each study were determined and compared. In cases where intended target protist groups were unclear, context was used to identify the most likely intended target group

groups (Online Resource 2). Studies using a combination of morphological and molecular identification approaches are biased toward ciliates (Jung et al. 2015; Park et al. 2017a, 2017b). Thus, it is not surprising that the known diversity of non-testate amoeba Amoebozoa and Cercozoa, and freeliving flagellate Discoba, is much lower than that of ciliates and testate amoebae. Discobans (including euglenozoans) make up only a small part of the overall diversity and are recorded from only the NAP, SVL and EA. Cercozoa have been recorded from every region sampled, but this diversity is predominantly comprised of testate amoebae ( 27 out of 39 total Cercozoa), while flagellate cercozoans only account for $23 \%$. Flagellate cercozoans, and other flagellate lineages, are likely to be more abundant and ubiquitous in Antarctic soils and mosses than the current data suggests since these organisms are a dominant component of terrestrial ecosystems in temperate climates (Geisen et al. 2014, 2015; Venter et al. 2018), largely due to their small size and rapid response time to environmental changes (Foissner 1991). Cercozoa have an overall lower richness than Ciliophora (Fig. 2A), probably because many soil flagellates have superficially similar morphologies, which coupled with their small size (many are less than 10 microns in length) makes them easier to overlook and harder to identify (Boenigk 2008; Venter et al. 2018). Future studies focusing on flagellate morphogroups specifically will be necessary to better understand phagotrophic protist diversity and function in these ecosystems.

Only 19 of the 236 identified species were encountered in three or more regions (Online Resource 3) and could potentially be considered members of most communities across the continent. On the other hand, if regional protist source pools were isolated during the LGM, then these seemingly widespread taxa could instead be distinct members of cryptic species complexes, descended from taxa that were widely distributed on the continent prior to increased glaciation during the LGM. In an analogous ecological event, Singer et al. (2019) found that sympatric speciation created a cryptic species complex in the testate amoeba Hyalosphenia papilio Leidy, 1874 after glacial retreat following the LGM in North America and Eurasia. Alternatively, these 19 widely occurring taxa could have a higher rate of dispersal due to their ecology (i.e., associations with moss or bird-influenced soils) or ecophysiology (cryptobiotic capabilities or greater habitat plasticity) (Foissner 1987), and could have arrived recently (after the LGM) from proximal, non-Antarctic source pools (Fernández 2015) or recolonized more broadly and more quickly than other LGM refugia protistan taxa. Yang et al. (2010) found that protists less than $100-150 \mu \mathrm{m}$ in length are more likely to be distributed across large distances (i.e., the Arctic and the Antarctic) and most of the 19 taxa are indeed within this size range. To see whether this trend held for the less widely distributed taxa, I plotted testate amoebae test lengths (Decloître 1960, 1964; Siemensma 2021) against bioregion occurrence counts (Online Resource 4, Fig. S2). Although a majority of testate amoeba not among the 19 widely distributed species were also under $100 \mu \mathrm{m}$ in length, none of the taxa longer than $100 \mu \mathrm{m}$ occurred in more than two regions. In any case, the study of the phylogenetics and ecology of these 19 taxa may warrant greater emphasis than others.

Of the 19 species found in three or more regions, nine were testate amoebae (four Amoebozoa and five Cercozoa), nine were Ciliophora, one was a cercozoan flagellate, and none were naked amoebae. The most widespread taxon was Corythion dubium Taránek, 1881 (a cercozoan testate amoeba) which occurred in eight of the 11 regions studied, including on nunataks in MBL (Broady 1989) and probably in EBL (Hada 1966). The broad distribution of C. dubium is noted by other authors (Broady et al. 1987; Royles et al. 2016) and this taxon may owe its wide distribution to being strongly r-selected and possessing other unique physiological adaptations (Smith 1985; Petz and Foissner 1997). Pseudoplatyophrya nana (Kahl, 1926) (Ciliophora) was found in five of the biodiversity regions. Seven species were found in four of the biodiversity regions, Assulina muscorum Greeff, 1888 (Cercozoa), Centropyxis aerophila Deflandre, 1929 (Amoebozoa), Colpoda cucullus (Müller, 1773) (Ciliophora), Colpoda inflata (Stokes, 1884), Colpoda steinii Maupas, 1883, Euglypha rotunda Wailes and Penard, 1911 (Cercozoa), and Leptopharynx costatus Mermod, 1914 (Ciliophora), while 10 were found in three biodiversity regions and 25 were found in two regions, leaving 192 identified species that were only found in a single region- $81 \%$ of total identified species. Twelve of the most widely distributed taxa were found outside of the best studied bioregions (NAP, EBL, EA and SVL) and their recovery may indicate their relative dominance in their respective habitats: C. dubium, A. muscorum, E. rotunda, Heteromita globosa (Stein, 1878), Trinema lineare Penard, 1890, L. costatus, P. 
nana and Paradileptus elephantinus (Svec, 1897), Difflugia lucida Penard, 1890, C. inflata, C. aerophila, and Homalogastra setosa Kahl, 1926.

\section{Phagotrophic protist diversity across habitat types}

The habitat with the highest phagotrophic protist diversity for all regions was 'Moss' (116 unique species), followed by 'Soil and Moss' (50 species) and then 'Soil' (35 species) (Fig. 5A). 'Moss' was the habitat with the highest taxonomic richness in NAP, while 'Soil and Moss' had the highest richness in EA and SVL (Fig. 5B). Species richness in 'Soil' was greatest in SVL but it was entirely absent from EBL. There were more studies in NAP that targeted moss habitats exclusively than targeted soils or moss and soils ( 3:1 moss to soil ratio), and thus, our understanding of phagotrophic protist diversity in NAP is likely biased toward moss species. Some taxa assigned to 'Moss' may actually occur in Antarctic mineral soil, inhabiting the soil directly under moss beds or the soil that has been blown over moss beds. Ciliophora and Amoebozoa (mostly testate amoebae) are the most species-rich groups in 'Moss', while Ciliophora diversity dominates 'Soil' and 'Soil and Moss' habitats (Fig. 5A). Heterotrophic flagellates from Cercozoa, Discoba, and Stramenopiles are equally diverse in 'Soils' (15 of 18 species) and 'Moss' (14 of 18; Online Resource 3). That ciliate richness is highest in all habitats is not consistent with the expected dominance of Amoebozoa and Cercozoa in arid soil environments (Geisen et al. 2014), though the simplicity of the habitat type categories may be concealing environmental nuances, like moisture gradients in unvegetated, mineral soils (Niederberger et al. 2015). Smith (1996) observed that ciliates were only significant proportions of the soil community in guano-influenced sites (regardless of moisture content) and Bamforth et al. (2005), sampling mineral soils, noted that ciliates and testate amoebae were not common. Conversely, Petz (1997) reported that, on average, $74 \%$ of their soil and moss samples contained ciliates. The diversity of Antarctic soil phagotrophic protist communities at the local scale is low and consists of primarily euryoecious, r-selected species. For example, Foissner (1996) found an average of 2.2 ciliate species per 10 to $50 \mathrm{~g}$ of sample in their Antarctic sites (NAP and SVL), in contrast to $>10$ ciliate species per similarly-sized samples from nonAntarctic sites. Bamforth et al. (2005) (SVL) recorded only 1-6 flagellate species from each site (each site consisted of 2 to 12 samples, with $1 \mathrm{~g}$ of soil examined from each sample), nearly an order of magnitude lower than estimates of soil flagellate diversity in temperate sites (Foissner 1991). Naked amoebae in SVL soils are common, but primarily consist of Acanthamoeba sp. and Vermamoeba (= Hartmannella) sp. (Bamforth et al. 2005). In Antarctic moss communities, C. dubium, T. lineare, C. aerophila, A. muscorum, D. $l u c i d a$ and $E$. rotunda are most frequent and most abundant (Smith 1987; Golemansky and Todorov 2004; Mieczan and Tarkowska-Kukuryk 2014).

Of the 19 species found in three or more regions, 15 were recovered from both soil and moss environments, while 2 were recovered from only moss, which is unexpected as moss-dwelling phagotrophic protists in Antarctica are more

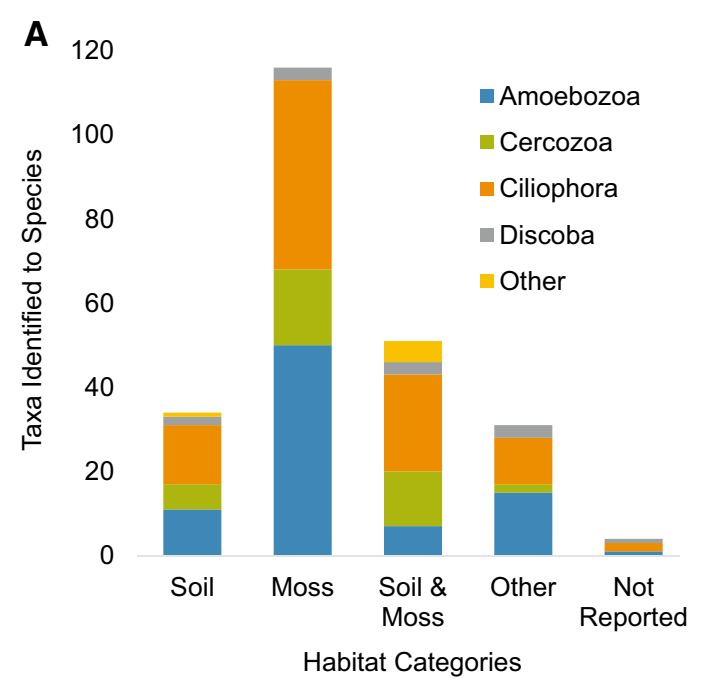

Fig. 5 Taxa by habitat and by region. A Breakdown of the number of taxa identified to species by habitat in each region. Taxa were assigned to categories based on sample and habitat descriptions from their original studies. "Soil" and "Moss" categories include taxa recorded from only soil or moss habitats. "Soil and Moss" include taxa found in both habitats in a single study or independently in both

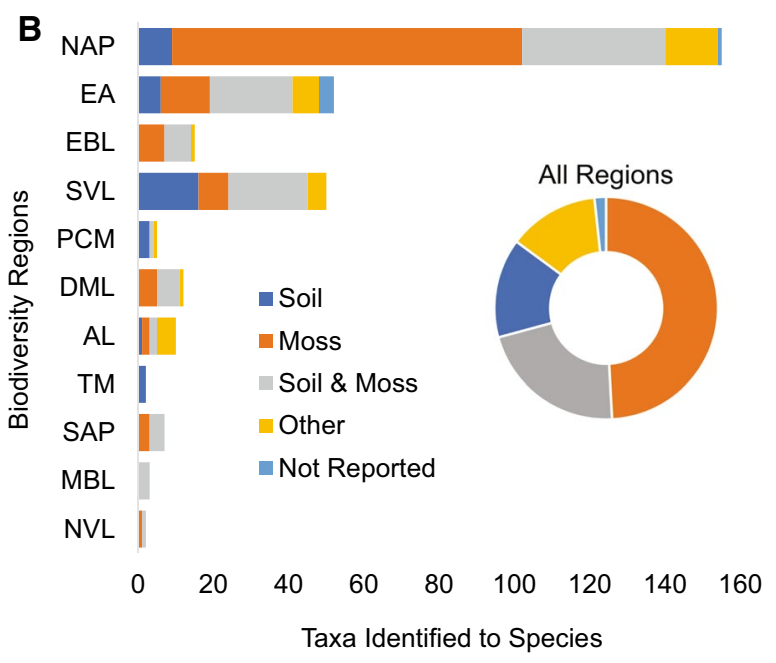

habitats from different studies. "Other" includes vegetated soils (not including moss-covered soils), ornithogenic derived habitats, and ambiguously reported samples. Species with no associated or discernible habitat information are those "Not Reported". There are no taxa that occur in more than one category. B Phylum/supergroup-level composition in each habitat category 
than twice as diverse as those recovered from soil and moss (Fig. 5A). However, broadly distributed species may possess relatively high ecological plasticity, explaining why most of the 19 "cosmopolitan" Antarctic taxa were recovered from both soil and moss habitat types. Only one of the 19 widely distributed species was found exclusively in soils, the globally distributed flagellate $H$. globosa. This morphospecies has recently been split into 5 novel genera and 29 novel species (Howe et al. 2009) and there are probably a variety of distinctly Antarctic H. globosa species, but it is not possible to retroactively identify the exact species isolated by the authors reviewed here (Sandon and Cutler 1924; Lawley et al. 2004; Bamforth et al. 2005). The H. globosa group of flagellates is frequently considered to be one of the most important phagotrophic protists in terms of its abundance, ubiquity, and role as a bacterial grazer (Howe et al. 2009) and future research into the distribution, diversity, and ecology of this species complex will be needed to fully understand the function of Antarctic soil ecosystems.

\section{Drivers of community structure}

\section{Abiotic factors}

The relative influence of various abiotic factors on the distribution and structure of phagotrophic protists generally is still an open question (Geisen et al. 2017). Antarctic terrestrial habitats, especially mineral soils, may prove useful in answering this question because these ecosystems are often primarily driven by abiotic processes (Hogg et al. 2006; Lee et al. 2019). In this section, I discuss what is known concerning the influence of soil moisture, temperature, $\mathrm{pH}$, salinity, oligotrophy, UV radiation, and soil texture on Antarctic phagotrophic protist communities.

The diversity and abundance of Antarctic phagotrophic protists appear to be positively correlated with moisture gradients, with soils ranging from wetter sites associated with productive moss covers to hyperarid unvegetated mineral soils (Smith 1974; Petz 1997; Thompson et al. 2020). Fell et al. (2006) found the highest diversity of microeukaryotes (including fungus and micro-metazoa) between the relatively moist (for Antarctica) levels of 3.1 and $4.9 \%$ soil moisture (gravimetric water content) and some unidentified eukaryotes were found where soil moisture levels were as low as $0.2 \%$. Small flagellates and naked amoebae tend to dominate arid soils (Smith 1996; Bamforth et al. 2005; Bates et al. 2013), probably due to their smaller size (lower resource needs) and the fact that they can be mobile in far less water (Geisen et al. 2014). Flagellates increased with increasing soil moisture (whether in terms of abundance or richness is not clear) but amoebae did not (Bamforth et al. 2005), potentially because amoebae are considered soil water film specialists and may not benefit from additional moisture (Geisen et al. 2014, 2015). Ciliates are usually free swimming and may be therefore restricted by lower moisture levels (Smith 1974; Bamforth et al. 2005). Velasco-Castrillón et al. (2014) found ciliates across a range of moistures, but most $(\sim 80 \%)$ were recovered from sites with $10 \%$ or greater moisture content (not specified, but presumably gravimetric water content). Conversely, a Spathidium sp. occurred far more frequently in arid soils ( 1 to $~ 8 \%$ moisture) than wetted ones (Niederberger et al. 2015). In temperate zones, testate amoebae are structured by moisture, but this relationship does not appear to hold in mosses from the NAP (Royles et al. 2016). A decreasing test size with increasing latitude along the peninsula in $C$. dubium could be an adaptive response to thinner water films in more southerly locations, but this relationship is hard to disentangle from confounding variables, e.g., trophic interactions, energetics or dispersal ability (Roland et al. 2017). Testate amoebae are restricted to moss habitats (Smith 1972, 1985, 1996) or occur in soils, but with a higher diversity in mosses (Sudzuki 1979; Petz 1997). Single, empty tests were at times found in mineral soils (Broady et al. 1987; Bamforth et al. 2005) and in soils associated with crustal algae or lichens (Broady et al. 1987).

Extreme low temperatures can be another limiting factor to many species because they reduce molecular rates, promote ice formation in the cytoplasm that can lyse cells, and reduce the availability of liquid water (De Maayer et al. 2014; Kolb 2014). Some Antarctic phagotrophic protists are known to exhibit varying degrees of psychrotolerance (Smith 1996; Bamforth et al. 2005), though distinguishing between the local soil temperature measured and the actual temperature endured by the organisms is a challenge (Convey et al. 2018). H. globosa and T. rostratus Perty, 1852 are facultative psychrophiles, and despite having optimal growth temperatures above $20^{\circ} \mathrm{C}$, both exhibit growth at or below $5{ }^{\circ} \mathrm{C}$ (Smith 1996). The non-endemic ciliate Colpoda maupasi Enriques, 1908 has been found at $-1.6^{\circ} \mathrm{C}$ in EA (Petz 1997), but additional investigation could reveal that the population is an unrelated cryptic species. A tendency toward a psychrotolerant rather than a psychrophilic lifestyle could result from the dramatic variation in Antarctic temperatures between seasons and even day to day (Sudzuki 1964; Knox et al. 2015). During the summer months, soil temperatures above $10{ }^{\circ} \mathrm{C}$ are not uncommon, even at high latitudes, such as in the McMurdo Dry Valleys (Doran et al. 2002). These temperatures could give mesophiles the edge over true psychrophiles, given they are able to survive (probably through encystment) the harsher spring, fall and winter climates. It is also possible that culturing techniques are biased toward mesophile ranges and growth times (Janetschek 1963, Brown 1982, Bamforth et al. 2005).

Beyond moisture and low temperatures, $\mathrm{pH}$, salinity, oligotrophy, increased UV radiation, and soil texture impose 
strong selection on community composition, especially in the more extreme mineral soils (Virginia and Wall 1999; Barrett et al. 2006a). Species representing most major clades have been recovered from soils ranging from $\mathrm{pH} 4$ to $\mathrm{pH} 9$ (Smith 1985; Petz and Foissner 1996, 1997; Petz 1997; Park et al. 2017b), and Smith (1992) observed that $\mathrm{pH}$ shaped testate amoeba community structure. Ciliate biomass correlated with $\mathrm{pH}$ in a study from Wilkes Land Antarctica (EA), potentially because $\mathrm{pH}$ is a major driver of their bacterial prey (Petz 1997). Although Bates et al. (2013) found no significant relationship between $\mathrm{pH}$ and protist diversity overall, mounting evidence of species-specific interactions between phagotrophic protists and their prey lends support to the connection (Glucksman et al. 2010; Saleem et al. 2013). Nutrient amendment studies show that limited carbon, nitrogen, and phosphorus are drivers of microbial communities in Antarctic soils (Buelow et al. 2016; Aanderud et al. 2018), but do not explore the response of the phagotrophic protist community. Virtually no stratification of organic carbon exists in dry soils farthest from streams and lake margins (Elberling et al. 2006), suggesting that arid sites may be carbon limited due to decreased photosynthesis near the soil surface. This nutrient limitation might select for smaller species than could survive in a more carbon rich environment. The impact of soil salinity on Antarctic phagotrophic protists is poorly investigated. Velasco-Castrillón et al. (2014) reported that ciliates were limited to soils with an electrical conductivity range of 0.4 to $4.4 \mathrm{dS} / \mathrm{m}$, much lower than reported in non-Antarctic soils (Kuppers et al. 2009). No work exists on the effects of soil salinity on flagellates (i.e., Cercozoa, Discoba and others), testate, or naked amoebae in these ecosystems. To date, no studies have evaluated the effects of UV radiation on near-surface taxa or of soil pore size on community structure, though Gokul et al. (2013) suggested that smaller pores may shelter certain species during the harsh Antarctic winter.

High variability of many of these parameters, notably water availability and temperature, has been cited as one of the harshest pressures for life on the continent (Peck et al. 2006; Chown and Convey 2007; Yergeau 2014). Some have suggested that the Antarctic environment has selected for small or medium-sized $(5-50 \mu \mathrm{m}) \mathrm{r}$-selected species which are best suited to deal with this variability, for example Acanthamoeba sp., Colpoda sp. and C. dubium (Foissner 1996; Petz 1997; Bamforth et al. 2005). Species known to be k-selected are present, e.g., Hartmanella sp. and Bodo sp. (Bamforth et al. 2005), so how significant the skew toward $\mathrm{r}$-selection actually is remains unclear.

Many phagotrophic protists form cysts to endure stressful environmental periods, but this is not a universal ability (Geisen et al. 2018). H. globosa (Cercozoa)-found in soils in the NAP, SVL, and TM (Sandon and Cutler 1924; Lawley et al. 2004; Bamforth et al. 2005)—can encyst due to cold temperatures alone (Smith 1996), while a taxon identified as Bodo saltans (Discoba) does not encyst and yet was found frequently in soil, moss, and other habitats from the NAP and SVL (Smith 1978; Bamforth et al. 2005). Encysted protists have been found to be viable after decades or even millennia (Lewis and Trainor 2012; Shmakova et al. 2016), and phagotrophic protist communities in Antarctica may be able to persist in inhospitable conditions for similar periods of time (Matsuo et al. 2018). Phagotrophic protists spend much of their time encysted, waiting for optimal conditions to arise before excysting to eat and reproduce (Bamforth 2001; Adl and Gupta 2006). The transition from dormant to active can happen relatively quickly, altering community composition and structure on very brief time scales (Bamforth 2001; Adl and Gupta 2006).

Encystment also allows some protists to survive passive dispersal (especially aeolian) and thereby helps to determine regional species pools (Foissner 1987; Lessard et al. 2012; Fernández 2015; Fernández et al. 2017), yet it is largely unknown how phagotrophic protist dispersal affects community structure in Antarctica. Smith (1985) discussed the effects of dispersal on fresh tephra on Deception Island in the late 1970s. Smith noted that a period of 10-30 months was required for any colonization to occur, and that small flagellates and amoebae were the first phagotrophic protists to arrive (Smith 1974, 1985), while testate amoebae were found only after a site had been vegetated for some time (Smith 1985). Smith also found that while time was correlated to an increase in protozoan diversity, a stronger driver was the arrival of moss propagules. This is likely due to moss-colonized soil retaining more moisture and providing higher niche diversity, greater nutrient concentrations (via photosynthesis), and an increase in pore size and variability (Smith 1985), itself a strong driver of phagotrophic protist diversity (Rønn et al. 2012; Geisen et al. 2014). Despite the evidence for dispersal among Antarctic phagotrophic protists, some authors reported high local heterogeneity (Smith 1974; Bamforth et al. 2005; Niederberger et al. 2015). Conversely, Obbels et al. (2016) observed a high degree of shared diversity across habitat types but point out that closely related species might have been obscured by their methodologies. The degree of species heterogeneity across the landscape could itself vary, with more homogeneity near sources of water and less in more arid areas (Fernández 2015). Heterogeneity could also indicate more the inhospitableness of landing site conditions than the lack of dispersal (Fernández 2015). A systematic study of heterogeneity in these ecosystems is needed as dispersal has a stabilizing effect on communities when local extinction rates are high (Sabelis and Diekmann 1988) (e.g., in 
extreme environments) but also encourages the invasion of non-native species (Lockwood et al. 2005).

\section{Biotic factors: co-occurrence and trophic interactions}

It is debated whether biological drivers are a major factor in structuring communities in Antarctic soils (Hogg et al. 2006) and nematode abundance and bacterial diversity were observed to be unrelated in SVL soils (Barrett et al. 2006b), although recent studies have shown that biotic drivers may be more significant than previously thought (Caruso et al. 2019; Lee et al. 2019), especially for protists (Thompson et al. in review). Most studies reviewed did not report cooccurrence between phagotrophic protists and other microbial groups (Online Resource 2). Those that did reported the presence of nematodes, tardigrades, and rotifers (the main groups of metazoa occurring in these ecosystems; Adams et al. (2006)), rarely utilized deliberate methodology for exploring the correlation between these groups, and none examined relationships between individual species. Bamforth et al. (2005) (SVL) reported that flagellates and amoebae co-occurred more frequently with nematode taxa than without, rarely with tardigrades and rotifers, and with ciliates only in the presence of other metazoan taxa. Declô̂tre (1964) (AL) also noted an absence of tardigrades and rotifers where phagotrophic protists (testate amoebae from moss, in this case) were found. In other studies, ciliate and tardigrade taxa were found co-occurring in every sample examined while few rotifers were recovered, and nematodes were entirely absent (Steele et al. 1994). Bates et al. (2013) (SVL) noted a relatively weak correlation between protistan and bacterial communities, though this study drew these conclusions from a collection of globally distributed sites that included Antarctica, so whether this pattern holds true independently in Antarctic soils is uncertain. A number of studies report moss species associations with specific phagotrophic protist species or community assemblages (Toriumi and Kato 1961; Sudzuki 1964; Mieczan and TarkowskaKukuryk 2014). Mieczan and Tarkowska-Kukuryk (2014) observed that moss species influenced ciliate body size but concluded that microsite physicochemical parameters had a greater influence on ciliate abundance and diversity than did host moss species.

Interactions between phagotrophic protist species and their respective prey can have a significant impact on community structure and ultimately ecosystem functioning (Corno and Jurgens 2008; Glucksman et al. 2010; Hünninghaus et al. 2017; Gao et al. 2019; Thakur and Geisen 2019). Traditionally phagotrophic protists were viewed as uniformly bacterivorous, but recent work suggests that greater trophic diversity exists (e.g., facultative and obligate mycophagy, algavory, osmotrophy and predation) among even closely related phagotrophic protist species (Petz and Foissner 1997; Bjørnlund and Rønn 2008; Glucksman et al. 2010; Geisen et al. 2018). In Antarctic soils, algavory has been observed in Pseudonotohymena antarctica Park, Jung, Min and Kim (2016) (Park et al. 2017b) and Saccamoeba stagnicola Page, 1974 (Bamforth et al. 2005). Keronopsis helluo Penard, 1922 (Ciliophora) - a consumer of rotifers and other large ciliates-has been isolated from King George Island (NAP) (Park et al. 2017a), although this behavior has not yet been observed in Antarctic populations. Fungivorous taxa, P. nana (Ciliophora) from SVL and Grossglockneria acuta Foissner, 1980 from NAP and predatory species, such as Urosomoida antarctica Foissner, 1996, a ciliate from SVL which feeds on bacteria and possibly flagellates and naked amoebae (Foissner 1996) have also been reported. The predatory genus Spathidium (Ciliophora) occurred in three regions (NAP, EA, SVL-S1) and in a variety of habitats, and was more frequently recovered from guano sites than vegetated soils (Smith 1978). Colpodella edax (Klebs, 1892), found in SVL soils (Bamforth et al. 2005) and Peranemopsis trichophora (Ehrenberg, 1832) from NAP (Smith 1985), are known predators of colorless and photosynthetic flagellates (Simpson and Patterson 1996; Triemer 1997). Many bacterivores are also present, including the stramenopiles Oikomonas termo (Müller, 1773) and O. mutabilis Kent, 1880; the discoban T. rostratus; the cercozoan flagellates Cercomonas agilis (Moroff, 1904), C. vibrans (Sandon, 1927), C. crassicauda Dujardin, 1841, Cercomonas longicauda Dujardin, 1841 and $H$. globosa; the cercozoan testate amoebae $C$. and $T$. lineare Penard, 1890; and the ciliophorans $C$. steinii and C. cucullus.

\section{Methodological biases and challenges}

\section{Study distribution}

Diversity estimates are influenced by the uneven distribution of studies across regions and the asymmetric sampling effort of each of those studies (Fig. 1). Intra-continental regions (e.g., SVL, North Victoria Land (NVL), TM, and Prince Charles Mountains (PCM)) have been the subject of fewer studies than higher latitude, coastal sites (e.g., EA and NAP), and two of the intra-continental sites (Ellsworth Land (EL) and Ellsworth Mountains (ELM)) remain completely unstudied (Fig. 2B, Fig. 1). Study density is strongly skewed toward NAP and SVL (Fig. 2B) and taxa counts for South Antarctic Peninsula (SAP), AL, TM, Marie Byrd Land (MBL), PCM, and DML are disproportionately lower. MBL and TM have been the focus of only one study, and NVL, PCM, SAP and AL of only two each. NAP has received the most attention by far with 25 studies, more than twice as many as the next most studied region, SVL, with 12 studies (Fig. 2B), while DML and EA have been the subject of 
5 and 6 studies, respectively. Possible explanations behind this geographic bias could include logistics-i.e., those regions that are the most accessible like NAP — and national resources allocated to science support. McMurdo station, by far the largest station in Antarctica, borders the Ross Sea region where the McMurdo Dry Valleys of SVL are located. From Fig. 1, it is apparent that even the sampling distribution across SVL itself is heavily biased toward areas within easy reach of McMurdo Station. Similar local biases occur in the NAP, DML and EA, despite their relatively high study number and taxonomic count.

\section{Accurately identifying phagotrophic protists}

The difficulty involved in accurately identifying protist species is perhaps the greatest challenge for assessing the function of phagotrophic protists in Antarctic soil communities. Morphological studies can suffer from a lack of distinguishing morphological characteristics and unknown culturing parameters (Boenigk 2008; Caron and Hu 2019). Distinguishing protists using only morphological traits has likely led to the "everything is everywhere" observation and hypothesis (e.g., Finlay (2002)), as there are probably far fewer morphospecies than genetically distinct cryptic species (Foissner 2008). Thus, it is probable that identifications made in morphological studies underestimate biodiversity (type II error; Adams (1998)) due to morphological convergence with well-known, globally distributed species. For example, three formerly recognized taxa in this dataset, Stylonychia mytilus, Nebela collaris (Ehrenberg, 1848), and C. aerophila are now considered to be species complexes (Foissner and Korganova 2000; Haentzsch et al. 2006; Kosakyan et al. 2013). Culture-based approaches are biased toward those taxa that respond best to the culturing conditions, regardless of their ecological significance, abundance, or functioning in the source environment (Smirnov and Brown 2004; Geisen et al. 2015). Some authors used the most probable number (MPN) method for isolating living protists from their samples (Steele et al. 1994), which has been shown to seriously alter community composition by creating conditions that selectively suit some protists over others (Foissner 1987; Berthold and Palzenberger 1995). More accurate techniques exist, such as the flooded petri dish method, and were used in some but not all studies reviewed (Luftenegger et al. 1988; Petz 1997), but the lack of standardization is a concern. In addition, morphological identifications are challenging for the inexperienced, and the training required to be able to make such distinctions satisfactorily is time consuming - as such, several authors did not identify protists past motility-based groupings, e.g., ciliates, flagellates, and amoebae (Steele et al. 1994; Barman 2000; Velasco-Castrillón et al. 2014). Molecular tools provide additional characters in the form of nucleotides, do not suffer from culturing biases, are generally more standardized, are easier for the taxonomically inexperienced to carry out, and have higher-throughput and greater data generation per unit time invested (Caron et al. 2009). However, molecular studies are also subject to biases: of the Antarctic studies that targeted the $18 \mathrm{~S}$ ribosomal RNA gene, none targeted the same region (Hodgson et al. 2010; Jung et al. 2015; Tyml et al. 2016; Park et al. 2017b). PCR amplification (a key step in many molecular-based approaches) and DNA extraction protocols (Santos et al. 2015) also alter community composition (Geisen et al. 2015; Guo et al. 2016) and species identification from molecular data alone, especially single gene studies, can be misleading (Caron et al. 2009; Pawlowski and Burki 2009; Caron and Hu 2019). A paucity of adequate reference sequences in properly curated databases and relatively arbitrary clustering based on sequence similarities can make identifications difficult and often unreliable (Lawley et al. 2004; Caron et al. 2009; Obbels et al. 2016). PCR bias can be mitigated by shotgun metagenomic studies, but differences in sequencer model and bioinformatic pipelines used can also bias results (Czechowski et al. 2016). Finally, deciding appropriate similarity binning cutoffs and how to treat singletons (real or artifacts) introduces a degree of subjectivity into these analyses that can lead to under- or overestimating true taxonomic diversity.

\section{A lack of a standardized approach}

The assessment of protist diversity in Antarctica has been subject to a wide variety of approaches (Smith 1992; Foissner 1996; Bamforth et al. 2005; Czechowski et al. 2016). Differences include the amount of soil extracted, the number of sample replicates assessed, the culturing method (e.g., flooded Petri vs MPN) and temperature, the amount of time between sampling and processing, the level of taxonomic expertise, sampling depth, storage temperatures and transport conditions. Many studies stemmed from opportunistic sampling, owing to the great difficulty involved in successfully accessing the Antarctic continent, especially in the beginning (Richters 1907, 1908; Murray 1910; Penard 1911; Sandon and Cutler 1924). Other studies were more deliberate, involving well-designed sampling efforts across a wide range of locations and habitat types (Smith 1992; Foissner 1996; Bamforth et al. 2005; Czechowski et al. 2016). Some were even exclusively focused on protists (Smith 1978; Sudzuki 1979; Ryan et al. 1989; Bamforth et al. 2005), though frequently studies only included protists as part of a broader assessment (Broady et al. 1987; Broady 1989; Schwarz et al. 1993; Obbels et al. 2016). Even across more methodical studies, sampling depth was not consistent or even reported (Richters 1907, 1908; Murray 1910; Penard 1911, 1913; Sandon and Cutler 1924; Smith 1972, 1987). When sampling depth was reported, it ranged from 0 to $10 \mathrm{~cm}$ (Smith 1974, 
1978, 1985; Petz and Foissner 1996; Bamforth et al. 2005; Park et al. 2017b). Studies used a variety of sample storage temperatures and interim time prior to sample processing, but samples were always stored at temperatures consistent with their natural climate-i.e., between 20 and $-20{ }^{\circ} \mathrm{C}$. Freeze-thaw cycles have been shown to reduce survival of soil organisms in Antarctica (Knox et al. 2015), and while the effect of storage temperature and duration have not been specifically tested on phagotrophic protist diversity, Mieczan and Tarkowska-Kukuryk (2014) and Petz (1997) processed their samples immediately after sampling. Removing and storing Antarctic soil samples for later analysis likely decreases the diversity of the samples, and thus sample analysis should be performed as soon after sampling as possible (Petz 1997; Adl and Gupta 2006). Another factor that can affect biodiversity estimates is the volume of soil used for subsequent processing - whether for culture-based examinations, live extraction, or nucleotide extraction (Smith 1974, 1987; Fell et al. 2006; Bates et al. 2013). Finally, sample descriptions are frequently vague such that characterizing the difference between soil and moss taxa in this review, for example, became challenging. Moreover, soils near lakes and streams, while apparently dry during sampling, can be unknowingly subject to greater input of liquid water over a season than soils farther from these sources. In some cases, whether a sample was from near a lake margin or within it (Hada 1966; Chatterjee et al. 2000; Hodgson et al. 2010; Mieczan and Tarkowska-Kukuryk 2014) was unclear and as a result some studies were excluded from this study (Hada 1966; Chatterjee et al. 2000; Hodgson et al. 2010). A corollary to this challenge is the lack of sample coordinates or sufficiently detailed site description such that researchers could return to the sampled sites for future analyses (Richters 1908; Murray 1910; Penard 1913; Sandon and Cutler 1924; Smith 1972, 1974, 1978, 1987). Future assessments of diversity will need to include more detailed sample metadata if they are to be reliably used for drawing broader conclusions on Antarctic protist diversity.

\section{Insights and future studies}

There has been a wide diversity of approaches to assessing diversity, both methodologically and logistically. Whether and how much this variety of methods has biased diversity estimates is unknown, but a standardized approach would facilitate more accurate and comparable diversity assessments between study sites and across biodiversity regions. This standard approach should consist of both morphological and molecular assessments (Roland et al. 2017; Geisen et al. 2018). Of 53 studies from across a continent roughly half again as large as Australia, $67 \%$ were based on morphology alone, while $29 \%$ used only molecular data (Fig. 4). Six studies combined molecular and morphological data (Jung et al. 2015, 2016; Tyml et al. 2016; Park et al. 2017a, 2017b, 2018), yet none used both in a general diversity survey. Environmental DNA studies, especially high-throughput analyses of diversity like those in the burgeoning field of microbial metagenetics, are currently poorly equipped to generate data that inform morphology, physiology, and ecological function, especially in those microbial groups that have received less attention, like protists (Caron et al. 2004, 2009). Traditional methods, on the other hand, excel at these types of investigations, even considering the powerful potential of fields like environmental metagenomics and metatranscriptomics (Geisen et al. 2015). Both methods should use reliable techniques (i.e., direct counting over most probable number; Foissner (1987), Luftenegger et al. (1988), Foissner (1992), Berthold and Palzenberger (1995)), curated databases (e.g., PR2; Guillou et al. (2013)), consistent extraction protocols (Santos et al. 2015), and where possible, sequencing approaches that reduce bias and inform ecology as well as diversity (e.g., metatranscriptomics and shotgun metagenomics) (Guo et al. 2016). When targeted sequencing using primers is more reasonable, consider that current universal eukaryotic primers may not be appropriate for sampling all eukaryotic lineages equally (Geisen et al. 2015). For example, Bates et al. (2013) recovered primarily organisms from the AH/SAR supergroup (i.e., Plantae, Rhizaria, and Alveolata) but recovered little from the Discoba or Amoebozoa lineages. This is most striking in their study of the McMurdo dry valleys, where a number of Amoebozoa taxa were recovered using a culture-based approach (Brown 1982; Bamforth et al. 2005). Care should be taken to verify that the primers being used can indeed sample all lineages sufficiently (Fell et al. 2006), or that studies target smaller taxonomic groupings. Standardized sampling procedures should also account for the heterogeneity inherent in the field and the variability in permafrost depth across sites (Chown and Convey 2007; Doran et al. 2010; Priscu 2013; Convey et al. 2014). Sampling vegetated soils must involve careful separation of above- and belowground habitat space, while thorough description of sites and the procedures used should be included in the methods sections of associated publications. Sample processing should be carried out as soon as possible after sampling occurs, involve limited time in storage and transport, and include expert support (Petz 1997).

\section{Conclusion}

Most of the identified 236 species of phagotrophic soil protists known from continental and peninsular Antarctica are concentrated in only a handful of regions, namely the North Antarctic Peninsula, EA and SVL. Overall, most of this diversity is regionally unique and as of yet the diversity 
shared between regions does not show strong trends. $C$. dubium is the most common species in soil and moss, while H. globosa type cercozoan flagellates are the most widely distributed, exclusively soil species. More protist species have been found in moss than soil habitats. Understanding how phagotrophic protist diversity relates to ecosystem functioning in Antarctica will require future investigations into community structure, food web interactions, and functional redundancy. Characterizing food webs in the more extreme sites (e.g., SVL, Transantarctic Mountains, Ellsworth Land, Prince Charles Mountains) could be a feasible first step, owing to their relative lower diversity. Answering questions concerning the resiliency of soil ecosystems in the Antarctic in the face of climate change can be facilitated by understanding the specific contribution of key antarctic phagotrophic protists to nutrient cycling, the functional overlap between species, and the potential for local extinction of these taxa. A special focus on the effects of speciesspecific interactions on communities will also be important, including the susceptibility of key species to changes in temperature, moisture content, and invasive species. Such identification can be inferred from relative abundances (direct counting, metagenomics, and metatranscriptomics), trophic interactions (determined by stable isotope probes; Crotty et al. (2012)), and in vitro experiments using cultured isolates and mesocosms (Warren et al. 2003; Glucksman et al. 2010). Treating Antarctic terrestrial ecosystems as model systems for other microbial ecosystems worldwide (Priscu 2013) and recognizing phagotrophic protists as important elements of Antarctic ecosystems will deepen our understanding of community structure, stability, and nutrient cycling in soils and improve our ability to predict and mitigate the effects of major environmental disturbances (i.e., climate change) on soil ecosystems.

Supplementary Information The online version contains supplementary material available at https://doi.org/10.1007/s00300-021-02896-3.

Acknowledgements This research was funded by the National Science Foundation Grant \#OPP-1637708 and is a contribution to the McMurdo Dry Valleys Long Term Ecological Research (LTER) program. I would like to thank David Wilkinson, Leonardo D. Fernández, and an anonymous reviewer for their comments and feedback which greatly improved the quality of this manuscript. I would also like to thank Stuart Bamforth for his introduction to working with Antarctic protists, and Byron Adams for his insight and advice at various stages of this manuscript's development.

\section{Declarations}

Conflict of interest The authors declare that they have no conflict of interest.

Open Access This article is licensed under a Creative Commons Attribution 4.0 International License, which permits use, sharing, adaptation, distribution and reproduction in any medium or format, as long as you give appropriate credit to the original author(s) and the source, provide a link to the Creative Commons licence, and indicate if changes were made. The images or other third party material in this article are included in the article's Creative Commons licence, unless indicated otherwise in a credit line to the material. If material is not included in the article's Creative Commons licence and your intended use is not permitted by statutory regulation or exceeds the permitted use, you will need to obtain permission directly from the copyright holder. To view a copy of this licence, visit http://creativecommons.org/licenses/by/4.0/.

\section{References}

Aanderud ZT, Saurey S, Ball BA, Wall DH, Barrett JE, Muscarella ME, Griffin NA, Virginia RA, Adams BJ (2018) Frontiers in ecology and the environment. Front Microbiol 9:1401. https://doi.org/10. 3389/fmicb.2018.01401

Acuña-Rodríguez IS, Gianoli E, Carrasco-Urra F, Stotz GC, SalgadoLuarte C, Rios RS, Molina-Montenegro MA (2014) Antarctic ecology one century after the conquest of the South Pole: how much have we advanced? Bioscience 64:593-600. https://doi. org/10.1093/biosci/biu074

Adams BJ (1998) Species concepts and the evolutionary paradigm in modern nematology. J Nematol 30:1-21

Adams BJ, Bardgett RD, Ayres E, Wall DH, Aislabie J, Bamforth S, Bargagli R, Cary C, Cavacini P, Connell L, Convey P, Fell JW, Frati F, Hogg ID, Newsham KK, O'Donnell A, Russell N, Seppelt RD, Stevens MI (2006) Diversity and distribution of Victoria Land biota. Soil Biol Biochem 38:3003-3018. https://doi.org/10. 1016/j.soilbio.2006.04.030

Adl MS, Gupta VS (2006) Protists in soil ecology and forest nutrient cycling. Can J for Res 36:1805-1817. https://doi.org/10.1139/ x06-056

Adl SM, Simpson AGB, Farmer MA, Andersen RA, Anderson OR, Barta JR, Bowser SS, Brugerolle GUY, Fensome RA, Fredericq S, James TY, Karpov S, Kugrens P, Krug J, Lane CE, Lewis LA, Lodge J, Lynn DH, Mann DG, McCourt RM, Mendoza L, Moestrup O, Mozley-Standridge SE, Nerad TA, Shearer CA, Smirnov AV, Spiegel FW, Taylor MFJR (2005) The new higher level classification of eukaryotes with emphasis on the taxonomy of protists. J Eukaryot Microbiol 52:399-451. https://doi.org/10. 1111/j.1550-7408.2005.00053.x

Adl SM, Leander BS, Simpson AG, Archibald JM, Anderson OR, Bass D, Bowser SS, Brugerolle G, Farmer MA, Karpov S, Kolisko M, Lane CE, Lodge DJ, Mann DG, Meisterfeld R, Mendoza L, Moestrup Ø, Mozley-Stanridge SE, Smirnov AV, Spiegel FW (2007) Diversity, nomenclature, and taxonomy of protists. Syst Biol 56:684-689

Adl SM, Simpson AG, Lane CE, Lukeš J, Bass D, Bowser SS, Brown M, Burki F, Dunthorn M, Hamp V, Heiss A, Hoppenrath M, Lara E, leGall L, Lynn DH, McManus H, Mitchell EAD, MozleyStanridge SE, Parfrey LW, Pawlowski J, Rueckert S, Shadwick L, Schoch C, Smirnov AV, Spiegel FW (2012) The revised classification of the eukaryotes. J Eukaryot Microbiol 59:429-514. https://doi.org/10.1111/j.1550-7408.2012.00644.x

Adl SM, Bass D, Lane CE, Lukeš J, Schoch CL, Smirnov A, Agatha S, Berney C, Brown MW, Burki F, Cárdenas P, Čepička I, Chistyakova L, del Campo J, Dunthorn M, Edvardsen B, Eglit Y, Guillou L, Hampl V, Heiss AA, Hoppenrath M, James TY, Karnkowska A, Karpov S, Kim E, Kolisko M, Kudryavtsev A, Lahr DJG, Lara E, Le Gall L, Lynn DH, Mann DG, Massana R, Mitchell EAD, Morrow C, Park JS, Pawlowski JW, Powell MJ, Richter DJ, Rueckert S, Shadwick L, Shimano S, Spiegel FW, Torruella G, 
Youssef N, Zlatogursky V, Zhang Q (2019) Revisions to the classification, nomenclature, and diversity of eukaryotes. J Eukaryot Microbiol 66:4-119. https://doi.org/10.1111/jeu.12691

Bamforth SS (2001) Proportions of active ciliate taxa in soils. Biol Fertil Soils 33:197-203

Bamforth SS, Wall DH, Virginia RA (2005) Distribution and diversity of soil protozoa in the McMurdo Dry Valleys of Antarctica. Polar Biol 28:756-762. https://doi.org/10.1007/s00300-005-0006-4

Bardgett RD, van der Putten WH (2014) Belowground biodiversity and ecosystem functioning. Nature 515:505-511. https://doi.org/10. 1038/nature 13855

Barman RP (2000) Studies on the moss-inhabiting terrestrial invertebrate fauna of Schirmacher Oasis, East Antarctica, during the XVII Indian scientific expedition to Antarctica. Dep Ocean Dev $15: 169-183$

Barret JE, Virginia RA, Wall DH, Cary SC, Adams BJ, Hacker AL, Aislabie JM (2006) Co-variation in soil biodiversity and biogeochemistry in northern and southern Victoria Land, Antarctica. Antarct Sci 4:535-548. https://doi.org/10.1017/S095410200 6000587

Barrett JE, Virginia RA, Hopkins DW, Aislabie J, Bargagli R, Bockheim JG, Campbell IB, Lyons WB, Moorhead DL, Nkem JN, Sletten RS, Steltzer H, Wall DH, Wallenstein MD (2006a) Terrestrial ecosystem processes of Victoria Land, Antarctica. Soil Biol Biochem 38:3019-3034. https://doi.org/10.1016/j.soilbio. 2006.04.041

Barrett JE, Virginia RA, Wall DH, Cary SC, Adams BJ, Hacker AL, Aislabie JM (2006b) Co-variation in soil biodiversity and biogeochemistry in northern and southern Victoria Land, Antarctica. Antarct Sci 18:1-14. https://doi.org/10.1017/S095410200 6000587

Bates ST, Clemente JC, Flores GE, Walters WA, Parfrey LW, Knight R, Fierer N (2013) Global biogeography of highly diverse protistan communities in soil. ISME J 7:652-659. https://doi.org/10.1038/ ismej.2012.147

Bell T, Bonsall MB, Buckling A, Whiteley AS, Goodall T, Griffiths RI (2010) Protists have divergent effects on bacterial diversity along a productivity gradient. Biol Lett 6:639

Berthold A, Palzenberger M (1995) Comparison between direct counts of active soil ciliates (Protozoa) and most probable number estimates obtained by Singh's dilution culture method. Biol Fertility Soils 19:348-356. https://doi.org/10.1007/BF00336106

Bjørnlund L, Rønn R (2008) 'David and Goliath' of the soil food webflagellates that kill nematodes. Soil Biol Biochem 40:2032-2039. https://doi.org/10.1016/j.soilbio.2008.04.011

Block W (1994) Terrestrial ecosystems: Antarctica. Polar Biol 14:293300. https://doi.org/10.1007/BF00238443

Boenigk J (2008) The past and present classification problem with nanoflagellates exemplified by the genus Monas. Protist 159:319-337. https://doi.org/10.1016/j.protis.2008.01.001

Broady PA (1989) Survey of algae and other terrestrial bioa at EdwardVII Peninsula, Marie-Byrd-Land. Antarct Sci 1:215-224

Broady PA, Given D, Greenfield L, Thompson K (1987) The biota and environment of fumaroles on Mt Melbourne, northern Victoria Land. Polar Biol 7:97-113. https://doi.org/10.1007/BF00570447

Brown TCRK (1982) Amoeba from Antarctic soil and water. Appl Environ Microbiol 44:491-493

Buelow HN, Winter AS, Van Horn DJ, Barrett JE, Gooseff MN, Schwartz E, Takacs-Vesbach CD (2016) Microbial community responses to increased water and organic matter in the arid soils of the McMurdo Dry Valleys. Antarct Front Microbiol 7:1040. https://doi.org/10.3389/fmicb.2016.01040

Burkins MB, Virginia RA, Wall DH (2001) Organic carbon cycling in Taylor Valley, Antarctica: quantifying soil reservoirs and soil respiration. Glob Change Biol 7:113-125. https://doi.org/10.1046/j. 1365-2486.2001.00393.x
Burton-Johnson A, Black M, Fretwell PT, Kaluza-Gilbert J (2016) An automated methodology for differentiating rock from snow, clouds and sea in Antarctica from Landsat 8 imagery: a new rock outcrop map and area estimation for the entire Antarctic continent. Cryosphere 10:1665-1677

Cannone N, Convey P, Guglielmin M (2013) Diversity trends of bryophytes in continental Antarctica. Polar Biol 36:259-271. https:// doi.org/10.1007/s00300-012-1257-5

Caron DA, Hu SK (2019) Are we overestimating protistan diversity in nature? Trends Microbiol 27:197-205. https://doi.org/10.1016/j. tim.2018.10.009

Caron DA, Countway PD, Brown MV (2004) The growing contributions of molecular biology and immunology to protistan ecology: molecular signatures as ecological tools. J Eukaryot Microbiol 51:38-48. https://doi.org/10.1111/j.1550-7408.2004.tb00159.x

Caron DA, Countway PD, Savai P, Gast RJ, Schnetzer A, Moorthi SD, Dennett MR, Moran DM, Jones AC (2009) Defining DNAbased operational taxonomic units for microbial-eukaryote ecology. Appl Environ Microbiol 75:5797-5808. https://doi.org/10. 1128/AEM.00298-09

Caruso T, Hogg ID, Nielsen UN, Bottos EM, Lee CK, Hopkins DW, Cary SC, Barrett JE, Green TGA, Storey BC, Wall DH, Adams BJ (2019) Nematodes in a polar desert reveal the relative role of biotic interactions in the coexistence of soil animals. Commun Biol 2:63. https://doi.org/10.1038/s42003-018-0260-y

Chakraborty S, Pangga IB, Roper MM (2012) Climate change and multitrophic interactions in soil: the primacy of plants and functional domains. Glob Change Biol 18:2111-2125. https:// doi.org/10.1111/j.1365-2486.2012.02667.x

Chatterjee P, Sinha J, Das AK, Mitra B (2000) Studies on some antarctic testaceans-a community analysis. Ecol Environ Conserv 6:237-243

Chown SL, Convey P (2007) Spatial and temporal variability across life's hierarchies in the terrestrial Antarctic. Philos Trans R Soc Lond B 362:2307-2331. https://doi.org/10.1098/rstb.2006. 1949

Convey P, Gibson JA, Hillenbrand CD, Hodgson DA, Pugh PJ, Smellie JL, Stevens MI (2008) Antarctic terrestrial life-challenging the history of the frozen continent? Biol Rev Camb Philos Soc 83:103-117. https://doi.org/10.1111/j.1469-185X.2008.00034.x

Convey P, Stevens MI, Hodgson DA, Smellie JL, Hillenbrand C-D, Barnes DKA, Clarke A, Pugh PJA, Linse K, Cary SC (2009) Exploring biological constraints on the glacial history of Antarctica. Quat Sci Rev 28:3035-3048. https://doi.org/10.1016/j. quascirev.2009.08.015

Convey P, Chown SL, Clarke A, Barnes DKA, Bokhorst S, Cummings V, Ducklow HW, Frati F, Green TGA, Gordon S, Griffiths HJ, Howard-Williams C, Huiskes AHL, Laybourn-Parry J, Lyons WB, McMinn A, Morley SA, Peck LS, Quesada A, Robinson SA, Schiaparelli S, Wall DH (2014) The spatial structure of Antarctic biodiversity. Ecol Monogr 84:203-244. https://doi.org/10.1890/ 12-2216.1

Convey P, Coulson SJ, Worland MR, Sjöblom A (2018) The importance of understanding annual and shorter-term temperature patterns and variation in the surface levels of polar soils for terrestrial biota. Polar Biol 41:1587-1605. https://doi.org/10.1007/ s00300-018-2299-0

Corno G, Jurgens K (2008) Structural and functional patterns of bacterial communities in response to protist predation along an experimental productivity gradient. Environ Microbiol 10:2857-2871. https://doi.org/10.1111/j.1462-2920.2008.01713.x

Crotty FV, Adl SM, Blackshaw RP, Murray PJ (2012) Protozoan pulses unveil their pivotal position within the soil food web. Microb Ecol 63:905-918. https://doi.org/10.1007/s00248-011-9956-y

Czechowski P, Clarke LJ, Breen J, Cooper A, Stevens MI (2016) Antarctic eukaryotic soil diversity of the Prince Charles Mountains 
revealed by high-throughput sequencing. Soil Biol Biochem 95:112-121. https://doi.org/10.1016/j.soilbio.2015.12.013

De Maayer P, Anderson D, Cary C, Cowan DA (2014) Some like it cold: understanding the survival strategies of psychrophiles. EMBO Rep 15:508-517. https://doi.org/10.1002/embr.20133 8170

Decloître L (1960) Thécamoebiens de la 8-ème Expédition Antarctique Française. Bull Mus Hist Nat, 2-Ème Série 32:242-251

Decloître L (1964) Thécamoebiens de la Douxième Expédition Antarctique Française en Terre Adélie. Exped Pol Franç 259:47

Doran PT, McKay CP, Clow GD, Dana GL, Fountain AG, Nylen T, Lyons WB (2002) Valley floor climate observations from the McMurdo Dry Valleys, Antarctica, 1986-2000. J Geophys Res Atmos. https://doi.org/10.1029/2001JD002045

Doran PT, Lyons WB, McKnight DM (2010) Life in Antarctic deserts and other cold dry environments: astrobiological analogs. Cambridge University Press, Cambridge

Elberling B, Gregorich EG, Hopkins DW, Sparrow AD, Novis P, Greenfield LG (2006) Distribution and dynamics of soil organic matter in an Antarctic Dry Valley. Soil Biol Biochem 38:30953106. https://doi.org/10.1016/j.soilbio.2005.12.011

Fell JW, Scorzetti G, Connell L, Craig S (2006) Biodiversity of microeukaryotes in Antarctic Dry Valley soils with $<5 \%$ soil moisture. Soil Biol Biochem 38:3107-3119. https://doi.org/10.1016/j.soilb io.2006.01.014

Fernández LD (2015) Source-sink dynamics shapes the spatial distribution of soil protists in an arid shrubland of northern Chile. J Arid Environ 113:121-125. https://doi.org/10.1016/j.jaridenv. 2014.10.007

Fernández LD, Hernández CE, Schiaffino MR, Izaguirre I, Lara E (2017) Geographical distance and local environmental conditions drive the genetic population structure of a freshwater microalga (Bathycoccaceae; Chlorophyta) in Patagonian lakes. FEMS Microbiol Ecol. https://doi.org/10.1093/femsec/fix125

Finlay BJ (2002) Global dispersal of free-living microbial eukaryote species. Science 296:1061-1063. https://doi.org/10.1126/scien ce. 1070710

Foissner W (1987) Soil protozoa: fundamental problems, ecological significance, adaptations in ciliates and testaceans, bioindicators, and guide to the literature. In: Corliss JO, Patterson DJ (eds) Progress in protistology. Biopress, Bristol, pp 69-212

Foissner W (1991) Diversity and ecology of soil flagellates. In: Patterson DJ, Larsen J (eds) Systematics association special volumes. Clarendon Press, Oxford, pp 93-112

Foissner W (1992) Estimating the species richness of soil protozoa using the "non-flooded petri dish method." In: Lee RJ, Soldo AT (eds) Protocols in protozoology. Allen Press, Lawrence, Kansas

Foissner W (1996) Faunistics, taxonomy and ecology of moss and soil ciliates (Protozoa, Ciliophora) from Antarctica, with description of new species, including Pleuroplitoides smithi gen. n., sp. n. Acta Protozool 35:95-123

Foissner W (1998) An updated compilation of world soil ciliates (Protozoa, Ciliophora), with ecological notes, new records, and descriptions of new species. Eur J Protistol 34:195-235

Foissner W (2008) Protist diversity and distribution: some basic considerations. Biodivers Conserv 17:235-242. https://doi.org/10. 1007/s10531-007-9248-5

Foissner W, Korganova GA (2000) The Centropyxis aerophila complex (Protozoa: Testacea). Acta Protozool 39:257-273

Fraser CI, Terauds A, Smellie J, Convey P, Chown SL (2014) Geothermal activity helps life survive glacial cycles. Proc Natl Acad Sci 111:5634-5639. https://doi.org/10.1073/pnas.1321437111

Gao Z, Karlsson I, Geisen S, Kowalchuk G, Jousset A (2019) Protists: puppet masters of the rhizosphere microbiome. Trends Plant Sci 24:165-176. https://doi.org/10.1016/j.tplants.2018.10.011
Geisen S (2016) The bacterial-fungal energy channel concept challenged by enormous functional versatility of soil protists. Soil Biol Biochem 102:22-25. https://doi.org/10.1016/j.soilbio.2016. 06.013

Geisen S, Bandow C, Römbke J, Bonkowski M (2014) Soil water availability strongly alters the community composition of soil protists. Pedobiologia 57:205-213. https://doi.org/10.1016/j.pedobi.2014. 10.001

Geisen S, Tveit AT, Clark IM, Richter A, Svenning MM, Bonkowski M, Urich T (2015) Metatranscriptomic census of active protists in soils. ISME J 9:2178-2190. https://doi.org/10.1038/ismej. 2015.30

Geisen S, Mitchell E, Wilkinson D, Adl S, Bonkowski M, Brown M, Fiore-Donno AM, Heger T, Jassey V, Krashevska V, Lahr D, Marcisz K, Mulot M, Payne R, Singer D, Anderson O, Charman D, Ekelund F, S. Griffiths B, Lara E, (2017) Soil protistology rebooted: 30 fundamental questions to start with. Soil Biol Biochem 111:94-103. https://doi.org/10.1016/j.soilbio.2017.04.001

Geisen S, Mitchell EAD, Adl S, Bonkowski M, Dunthorn M, Ekelund F, Fernandez LD, Jousset A, Krashevska V, Singer D, Spiegel FW, Walochnik J, Lara E (2018) Soil protists: a fertile frontier in soil biology research. FEMS Microbiol Rev 42:293-323. https:// doi.org/10.1093/femsre/fuy006

Glucksman E, Bell T, Griffiths RI, Bass D (2010) Closely related protist strains have different grazing impacts on natural bacterial communities. Environ Microbiol 12:3105-3113. https://doi.org/ 10.1111/j.1462-2920.2010.02283.x

Gokul JK, Valverde A, Tuffin M, Cary SC, Cowan DA (2013) Microeukaryotic diversity in hypolithons from Miers Valley, Antarctica. Biology (basel) 2:331-340. https://doi.org/10.3390/biolo gy2010331

Golemansky V, Todorov M (2004) Additional data and summarized check-list on the rhizopods (Rhizopoda: Amoebida \& Testacea) from Livingston Island, South Shetlands, the Antarctic. In: Golemansky V, Chipev N (eds) Bulgarian Antarctic research, life science. Pensoft Publishers, Sofia, pp 83-93

Goordial J, Davila A, Lacelle D, Pollard W, Marinova MM, Greer CW, DiRuggiero J, McKay CP, Whyte LG (2016) Nearing the cold-arid limits of microbial life in permafrost of an upper Dry Valley, Antarctica. Int Soc Microbial Ecol 10:1613-1624. https:// doi.org/10.1038/ismej.2015.239

Guillou L, Bachar D, Audic S, Bass D, Berney C, Bittner L, Boutte C, Burgaud G, de Vargas C, Decelle J, Del Campo J, Dolan JR, Dunthorn M, Edvardsen B, Holzmann M, Kooistra WH, Lara E, Le Bescot N, Logares R, Mahe F, Massana R, Montresor M, Morard R, Not F, Pawlowski J, Probert I, Sauvadet AL, Siano R, Stoeck T, Vaulot D, Zimmermann P, Christen R (2013) The Protist Ribosomal Reference database $\left(\mathrm{PR}^{2}\right)$ : a catalog of unicellular eukaryote small sub-unit rRNA sequences with curated taxonomy. Nucleic Acids Res 41:D597-604. https://doi.org/10. 1093/nar/gks1160

Guo J, Cole JR, Zhang Q, Brown CT, Tiedje JM (2016) Microbial community analysis with ribosomal gene fragments from shotgun metagenomes. Appl Environ Microbiol 82:157-166. https://doi. org/10.1128/aem.02772-15

Hada Y (1964) The fresh-water fauna of the protozoa in the region of the show station in Antarctica. Bull Suzuzg Women's Coll Nat Sci 11:5-21

Hada Y (1966) The freshwater fauna of the protozoa in the region of the Syowa station in Antarctica. JARE Sci Rep Spec 4:209-215

Haentzsch M, Schmidt SL, Bernhard D, Ammermann D, Berendonk TU, Schlegel M (2006) A PCR-based method to distinguish the sibling species Stylonychia mytilus and Stylonychia lemnae (Ciliophora, Spirotrichea) using isocitrate dehydrogenase gene 
sequences. J Eukaryot Microbiol 53:343-347. https://doi.org/10. 1111/j.1550-7408.2006.00111.x

Hodgson DA, Convey P, Verleyen E, Vyverman W, McInnes SJ, Sands CJ, Fernández-Carazo R, Wilmotte A, De Wever A, Peeters K, Tavernier I, Willems A (2010) The limnology and biology of the Dufek Massif, transantarctic mountains $82^{\circ}$ south. Polar Sci 4:197-214. https://doi.org/10.1016/j.polar.2010.04.003

Hogg ID, Cary SC, Convey P, Newsham KK, O’Donnell AG, Adams BJ, Aislabie J, Frati F, Stevens MI, Wall DH (2006) Biotic interactions in Antarctic terrestial ecosystems-are they a factor? Soil Biol Biochem 38:3035-3040. https://doi.org/10.1016/j.soilbio. 2006.04.026

Howe AT, Bass D, Vickerman K, Chao EE, Cavalier-Smith T (2009) Phylogeny, taxonomy, and astounding genetic diversity of Glissomonadida ord. nov., the dominant gliding zooflagellates in soil (Protozoa: Cercozoa). Protist 160:159-189. https://doi.org/10. 1016/j.protis.2008.11.007

Hünninghaus M, Koller R, Kramer S, Marhan S, Kandeler E, Bonkowski M (2017) Changes in bacterial community composition and soil respiration indicate rapid successions of protist grazers during mineralization of maize crop residues. Pedobiologia 62:1-8. https://doi.org/10.1016/j.pedobi.2017.03.002

Janetschek H (1963) On the terrestrial fauna of the Ross Sea area, Antarctica. Pac Insects 5:305-311

Jung J-H, Park K-M, Min G-S, Berger H, Kim S (2015) Morphology and molecular phylogeny of an Antarctic population of Paraholosticha muscicola (Kahl, 1932) Wenzel, 1953 (Ciliophora, Hypotricha). Polar Sci 9:374-381. https://doi.org/10.1016/j. polar.2015.08.005

Jung J-H, Park K-M, Kim S (2016) Morphological and molecular phylogeny of the soil ciliate Anteholosticha rectangula sp. nov. from King George Island. Antarct Acta Protozool 55:89-99. https:// doi.org/10.4467/16890027AP.16.008.4943

Knox MA, Wall DH, Virginia RA, Vandegehuchte ML, Gil IS, Adams BJ (2015) Impact of diurnal freeze-thaw cycles on the soil nematode Scottnema lindsayae in Taylor Valley, Antarctica. Polar Biol 39:583-592. https://doi.org/10.1007/s00300-015-1809-6

Kolb VM (2014) Astrobiology: an evolutionary approach. Taylor \& Francis Group, Bosa Roca

Kosakyan A, Gomaa F, Mitchell EAD, Heger TJ, Lara E (2013) Using DNA-barcoding for sorting out protist species complexes: a case study of the Nebela tincta-collaris-bohemica group (Amoebozoa; Arcellinida, Hyalospheniidae). Eur J Protistol 49:222-237. https://doi.org/10.1016/j.ejop.2012.08.006

Kuppers CG, Claps MC, Lopretto EC (2009) Ciliates (Protozoa) from dried sediments of a temporary pond from Argentina. Rev Mex Biodivers 80:581-592

Lawley B, Ripley S, Bridge P, Convey P (2004) Molecular analysis of geographic patterns of eukaryotic diversity in Antarctic soils. Appl Environ Microbiol 70:5963-5972. https://doi.org/10.1128/ AEM.70.10.5963-5972.2004

Lee CK, Laughlin DC, Bottos EM, Caruso T, Joy K, Barrett JE, Brabyn L, Nielsen UN, Adams BJ, Wall DH, Hopkins DW, Pointing SB, McDonald IR, Cowan DA, Banks JC, Stichbury GA, Jones I, Zawar-Reza P, Katurji M, Hogg ID, Sparrow AD, Storey BC, Allan Green TG, Cary SC (2019) Biotic interactions are an unexpected yet critical control on the complexity of an abiotically driven polar ecosystem. Commun Biol 2:62. https://doi.org/10. 1038/s42003-018-0274-5

Lessard J-P, Borregaard MK, Fordyce JA, Rahbek C, Weiser MD, Dunn RR, Sanders NJ (2012) Strong influence of regional species pools on continent-wide structuring of local communities. Proc Biol Sci 279:266-274

Lewis LA, Trainor FR (2012) Survival of Protosiphon botryoides (Chlorophyceae, Chlorophyta) from a Connecticut soil dried for 43 years. Phycologia 51:662-665. https://doi.org/10.2216/ 11-108.1

Lockwood JL, Cassey P, Blackburn T (2005) The role of propagule pressure in explaining species invasions. Trends Ecol Evol 20:223-228. https://doi.org/10.1016/j.tree.2005.02.004

Luftenegger G, Petz W, Foissner W, Adam H (1988) The efficiency of a direct counting method in estimating the numbers of microscopic soil organisms. Pedobiologia 31:95-101

Matsuo J, Nakamura S, Okubo T, Fukui M, Yamaguchi H (2018) Longterm survival of Naegleria polaris from Antarctica after 10 years of storage at $4^{\circ} \mathrm{C}$. Parasitol Res 117:937-941. https://doi.org/10. 1007/s00436-018-5779-9

Mieczan T, Tarkowska-Kukuryk M (2014) Ecology of moss dwelling ciliates from King George Island, Antarctic: the effect of environmental parameters. Polish Polar Res 35:609-625. https://doi. org/10.2478/popore-2014-0026

Murray J (1910) On microscopic life at Cape Royds. Br Antart Exped (1907-1909) 1:17-22

Niederberger TD, Sohm JA, Gunderson TE, Parker AE, Tirindelli J, Capone DG, Carpenter EJ, Cary SC (2015) Microbial community composition of transiently wetted Antarctic Dry Valley soils. Front Microbiol. https://doi.org/10.3389/fmicb.2015.00009

Nielsen UN, Ayres E, Wall DH, Bardgett RD (2011) Soil biodiversity and carbon cycling: a review and synthesis of studies examining diversity-function relationships. Eur J Soil Sci 62:105-116. https://doi.org/10.1111/j.1365-2389.2010.01314.x

Obbels D, Verleyen E, Mano MJ, Namsaraev Z, Sweetlove M, Tytgat B, Fernandez-Carazo R, De Wever A, D'Hondt S, Ertz D, Elster J, Sabbe K, Willems A, Wilmotte A, Vyverman W (2016) Bacterial and eukaryotic biodiversity patterns in terrestrial and aquatic habitats in the $S \varnothing r$ Rondane Mountains, Dronning Maud Land, East Antarctica. FEMS Microbiol Ecol 92:41. https://doi.org/10.1093/femsec/fiw041

Park KM, Chae N, Jung JH, Min GS, Kim S, Berger H (2017a) Redescription of Keronopsis helluo Penard, 1922 from Antarctica and Paraholosticha pannonica Gellert and Tamas, 1959 from Alaska (Ciliophora, Hypotricha). Eur J Protistol 60:102-118. https://doi.org/10.1016/j.ejop.2017.04.008

Park KM, Jung JH, Min GS, Kim S (2017b) Pseudonotohymena antarctica n. g., n. sp. (Ciliophora, Hypotricha), a new species from Antarctic Soil. J Eukaryot Microbiol 64:447-456. https:// doi.org/10.1111/jeu.12381

Park KM, Min GS, Kim S (2018) Morphology and phylogeny of a new species, Uroleptus (Caudiholosticha) antarctica n. sp. (Ciliophora, Hypotricha) from Greenwich Island in Antarctica. Zootaxa 4483:591-599. https://doi.org/10.11646/zoota xa.4483.3.10

Pawlowski J, Burki F (2009) Untangling the phylogeny of amoeboid protists. J Eukaryot Microbiol 56:16-25. https://doi.org/10. 1111/j.1550-7408.2008.00379.x

Peck LS, Convey P, Barnes DK (2006) Environmental constraints on life histories in Antarctic ecosystems: tempos, timings and predictability. Biol Rev Camb Philos Soc 81:75-109. https:// doi.org/10.1017/S1464793105006871

Penard E (1911) Sarcodina. Rhizopodes d'eau douce. W. Heinemann, London

Penard E (1913) Rhizopodes d'eau douce, par E. Pénard Deuxième Expéd Ant Franç 1908-1910:1-16

Petz W (1997) Ecology of the active soil microfauna (Protozoa, Metazoa) of Wilkes Land Antarctica. Polar Biol 18:33-44. https://doi.org/10.1007/s003000050156

Petz W, Foissner W (1996) Morphology and morphogenesis of Lamtostyla edaphoni Berger and Foissner and Onychodromopsis flexilis Stokes, two hypotrichs (Protozoa: Ciliophora) from Antarctic soils. Acta Protozool 35:257-280 
Petz W, Foissner W (1997) Morphology and infraciliature of some soil ciliates (Protozoa, Ciliophora) from continental Antarctica, with notes on the morphogenesis of Sterkiella histriomuscorum. Polar Rec 33:307-326

Potter KA, Arthur Woods H, Pincebourde S (2013) Microclimatic challenges in global change biology. Glob Change Biol 19:2932-2939. https://doi.org/10.1111/gcb.12257

Priscu J (2013) Ecosystem dynamics in a polar desert: the McMurdo Dry Valleys, Antarctica. American Geophysical Union, Washington

Richters F (1907) Die Fauna der Moosrasen des Gaussberges und einiger südlicher Inseln. Georg Reimer, Berlin

Richters F (1908) Moosbewohner. Wissenschaftliche Ergebnisse Schwedischen Südpolar-Expedition, Stockholm, 6:1-16

Roland TP, Amesbury MJ, Wilkinson DM, Charman DJ, Convey P, Hodgson DA, Royles J, Clauß S, Völcker E (2017) Taxonomic implications of morphological complexity within the testate amoeba genus Corythion from the Antarctic Peninsula. Protist 168:565-585. https://doi.org/10.1016/j.protis.2017.07.006

Rønn R, Vestergård M, Ekelund F (2012) Interactions between bacteria, Protozoa and nematodes in soil. Acta Protozool 51:223235. https://doi.org/10.4467/16890027AP.12.018.0764

Royles J, Amesbury MJ, Convey P, Griffiths H, Hodgson DA, Leng MJ, Charman DJ (2013) Plants and soil microbes respond to recent warming on the Antarctic Peninsula. Curr Biol 23:17021706. https://doi.org/10.1016/j.cub.2013.07.011

Royles J, Amesbury MJ, Roland TP, Jones GD, Convey P, Griffiths H, Hodgson DA, Charman DJ (2016) Moss stable isotopes (carbon-13, oxygen-18) and testate amoebae reflect environmental inputs and microclimate along a latitudinal gradient on the Antarctic Peninsula. Oecologia 181:931-945. https://doi. org/10.1007/s00442-016-3608-3

Ruggiero MA, Gordon DP, Orrell TM, Bailly N, Bourgoin T, Brusca RC, Cavalier-Smith T, Guiry MD, Kirk PM (2015) A higher level classification of all living organisms. PLoS ONE 10:e119248. https://doi.org/10.1371/journal.pone.0119248

Ryan PG, Watkins BP, Lewis Smith RI, Dastych H, Eicker A, Foissner W, Hl H, Miller WR, Thompson G (1989) Biological survey of Robertskollen western Dronning Maud Land Antarctica area description and preliminary species lists. S Afr J Antarct Res 19:10-20

Sabelis MW, Diekmann O (1988) Overall population stability despite local extinction: the stabilizing influence of prey dispersal from predator-invaded patches. Theor Popul Biol 34:169-176

Saleem M, Fetzer I, Dormann CF, Harms H, Chatzinotas A (2012) Predator richness increases the effect of prey diversity on prey yield. Nat Commun 3:1305. https://doi.org/10.1038/ncomm s2287

Saleem M, Fetzer I, Harms H, Chatzinotas A (2013) Diversity of protists and bacteria determines predation performance and stability. ISME J 7:1912-1921. https://doi.org/10.1038/ismej. 2013.95

Sandon H, Cutler DW (1924) Some protozoa from the soils collected by the quest expedition (1921-1922). J Linn Soc (zool) 36:1-12

Santos SS, Nielsen TK, Hansen LH, Winding A (2015) Comparison of three DNA extraction methods for recovery of soil protist DNA. J Microbiol Methods 115:13-19. https://doi.org/10.1016/j.mimet. 2015.05.011

Schwarz A-MJ, Green JD, Green TGA, Seppelt RD (1993) Invertebrates associated with moss communities at Canada Glacier, southern Victoria Land, Antarctica. Polar Biol 13:157-162. https://doi.org/10.1007/bf00238925

Shmakova L, Bondarenko N, Smirnov A (2016) Viable species of Flamella (Amoebozoa: Variosea) isolated from ancient arctic permafrost sediments. Protist 167:13-30. https://doi.org/10.1016/j. protis.2015.11.001
Siemensma FJ (2021) Microworld, world of amoeboid organisms. World-wide electronic publication, Kortenhoef, The Netherlands. https://www.arcella.nl/. Accesssed 8 March 2021

Simpson AGB, Patterson DJ (1996) Ultrastructure and identification of the predatory flagellate Colpodella pugnax Cienkowski (Apicomplexa) with a description of Colpodella turpis n. sp. and a review of the genus. Syst Parasitol 33:187-198. https://doi.org/ 10.1007/BF01531200

Singer D, Mitchell EAD, Payne RJ, Blandenier Q, Duckert C, Fernández LD, Fournier B, Hernández CE, Granath G, Rydin H, Bragazza L, Koronatova NG, Goia I, Harris LI, Kajukało K, Kosakyan A, Lamentowicz M, Kosykh NP, Vellak K, Lara E (2019) Dispersal limitations and historical factors determine the biogeography of specialized terrestrial protists. Mol Ecol 28:3089-3100. https://doi.org/10.1111/mec. 15117

Singer D, Seppey CVW, Lentendu G, Dunthorn M, Bass D, Belbahri L, Blandenier Q, Debroas D, de Groot GA, de Vargas C, Domaizon I, Duckert C, Izaguirre I, Koenig I, Mataloni G, Schiaffino MR, Mitchell EAD, Geisen S, Lara E (2021) Protist taxonomic and functional diversity in soil, freshwater and marine ecosystems. Environ Int 146:106262. https://doi.org/10.1016/j.envint.2020. 106262

Smirnov A, Brown S (2004) Guide to the methods of study and identification of soil gymnamoebae. Protistology 3:148-190

Smith HG (1972) The terrestrial protozoa of Elephant Island. Br Antarct Surv Bull 31:55-62

Smith HG (1974) The colonization of volcanic tephra on Deception Island by protozoa. Br Antarct Surv Bull 38:49-58

Smith HG (1978) Distribution and ecology of terrestrial protozoa of sub-Antarctic and maritime Antarctic islands. British Antarctic Survey, Cambridge, pp 1-104

Smith HG (1982) The terrestrial protozoan fauna of South Georgia. Polar Biol 1:173-179. https://doi.org/10.1007/BF00287004

Smith HG (1985) The colonisation of volcanic tephra on Deception Island: long term trends. Br Antarct Surv Bull 66:19-33

Smith HG (1987) A species-poor testate rhizopod fauna on Brabant Island. Br Antarct Surv Bull 77:173-176

Smith HG (1992) Distribution and ecology of the testate rhizopod fauna of the continental Antarctic zone. Polar Biol 12:629-634

Smith HG (1996) Diversity of Antarctic terrestrial protozoa. Biodivers Conserv 5:1379-1394. https://doi.org/10.1007/BF00051984

Steele WK, Balfour DA, Harris JM, Dastych H, Heyns J, Eicker A (1994) Preliminary biological survey of Vesleskarvet, northern Ahlmannrygen, western Queen Maud Land: site of South Africa's new Antarctic base. S Afr J Antarct Res 24:565-575

Sudzuki M (1964) On the microfauna of the Antarctic region, I. Mosswater community at langhovde. Jpn Antarct Res Exped Sci Rep 19:1-41

Sudzuki M (1979) On the microfauna of the Antarctic region. III. Microbiota of the terrestrial interstices. Jpn Antarct Res Exped Sci Rep 11:104-126

Terauds A, Lee JR (2016) Antarctic biogeography revisited—updating the Antarctic conservation biogeographic regions. Divers Distrib 22:836-840. https://doi.org/10.1111/ddi.12453

Terauds A, Chown SL, Morgan F, Peat HJ, Watts DJ, Keys H, Convey P, Bergstrom DM (2012) Conservation biogeography of the Antarctic. Divers Distrib 18:726-741

Thakur MP, Geisen S (2019) Trophic regulations of the soil microbiome. Trends Microbiol 27:771-780. https://doi.org/10.1016/j. tim.2019.04.008

Thompson AR, Roth-Monzón AJ, Aanderud ZT, Adams BJ (in review) Phagotrophic protists and their associates: evidence for preferential grazing in an abiotically driven soil ecosystem

Thompson AR, Powell GS, Adams BJ (2019) Provisional checklist of terrestrial heterotrophic protists from Antarctica. Antarct Sci 31:287-303. https://doi.org/10.1017/S0954102019000361 
Thompson AR, Geisen S, Adams BJ (2020) Shotgun metagenomics reveal a diverse assemblage of protists in a model Antarctic soil ecosystem. Environ Microbiol 22:4620-4632. https://doi.org/10. 1111/1462-2920.15198

Todorov M, Golemansky V (1996) Notes on testate amoebae (Protozoa: Rhizopoda) from Livingston Island, South Shetland Islands, Antarctic. In: Golemansky V, Chipev N (eds) Bulgarian Antarctic research life sciences. Pensoft Publishers, Sofia, pp 70-81

Toriumi M, Kato M (1961) Preliminary report on the microfauna and flora among the mosses from the Ongul Islands. Bull Mar Biol Stat Asam 10:231-237

Triemer RE (1997) Feeding in Peranema trichophorum revisited (Euglenophyta). J Phycol 33:649-654

Tyml T, Skulinova K, Kavan J, Ditrich O, Kostka M, Dykova I (2016) Heterolobosean amoebae from Arctic and Antarctic extremes: 18 novel strains of Allovahlkampfia, Vahlkampfia and Naegleria. Eur J Protistol 56:119-133. https://doi.org/10.1016/j.ejop. 2016.08.003

Velasco-Castrillón A, Schultz MB, Colombo F, Gibson JA, Davies KA, Austin AD, Stevens MI (2014) Distribution and diversity of soil microfauna from East Antarctica: assessing the link between biotic and abiotic factors. PLoS ONE 9:e87529. https://doi.org/ 10.1371/journal.pone.0087529

Venter PC, Nitsche F, Arndt H (2018) The hidden diversity of flagellated protists in soil. Protist 169:432-449. https://doi.org/10. 1016/j.protis.2018.04.007

Virginia RA, Wall DH (1999) How soils structure communities in the Antarctic Dry Valleys. Bioscience 49:973-983. https://doi.org/ 10.1525/bisi.1999.49.12.973

Wall DH (2005) Biodiversity and ecosystem functioning in terrestrial habitats of Antarctica. Antarct Sci 17:523-531. https://doi.org/ 10.1017/S0954102005002944
Wall DH (2007) Global change tipping points: above- and belowground biotic interactions in a low diversity ecosystem. Philos Trans R Soc Lond B 362:2291-2306. https://doi.org/10.1098/ rstb.2006.1950

Wardle DA (2006) The influence of biotic interactions on soil biodiversity. Ecol Lett 9:870-886. https://doi.org/10.1111/j.1461-0248. 2006.00931.x

Warren PH, Law R, Weatherby AJ (2003) Mapping the assembly of protist communities in microcosms. Ecology 84:1001-1011. https://doi.org/10.1890/0012-9658(2003)084[1001:MTAOPC] 2.0.CO;2

Wilkinson DM, Creevy AL, Valentine J (2012) The past, present and future of soil protist ecology. Acta Protozool 51:189-199. https:// doi.org/10.4467/16890027AP.12.015.0761

Yang J, Smith HG, Sherratt TN, Wilkinson DM (2010) Is there a size limit for cosmopolitan distribution in free-living microorganisms? A biogeographical analysis of testate amoebae from polar areas. Microb Ecol 59:635-645. https://doi.org/10.1007/ s00248-009-9615-8

Yergeau E (2014) Fell-Field Soil Microbiology. In: Cowan DA (ed) Antarctic terrestrial microbiology: physical and biological properties of Antarctic soils. Springer Berlin Heidelberg, Berlin, Heidelberg, pp 115-129

Publisher's Note Springer Nature remains neutral with regard to jurisdictional claims in published maps and institutional affiliations. 